\title{
Holocene landscape evolution of an estuarine wetland in relation to its human occupation and exploitation: Waasland Scheldt polders, northern Belgium
}

\author{
T. Missiaen ${ }^{1, *}$, I. Jongepier ${ }^{2}$, K. Heirman ${ }^{1,5}$, T. Soens ${ }^{2}$, V. Gelorini ${ }^{3}$, J. Verniers ${ }^{3}$, J. Verhegge ${ }^{4}$ \\ \& Ph. Crombé ${ }^{4}$
}

1 Renard Centre of Marine Geology, Ghent University, Krijgslaan 281 S8, B9000 Ghent, Belgium

2 Department of History, University of Antwerp, Stadscampus, S.R-A.112, Rodestraat 14, B2000 Antwerp, Belgium

3 Palaeontology Research Unit, Ghent University, Krijgslaan 281 S8, B9000 Ghent, Belgium

4 Department of Archaeology, Ghent University, Sint-Pietersnieuwsstraat 35, B9000 Ghent, Belgium

5 Currently at Geological Survey of Denmark and Greenland, $\emptyset$. Voldgade 10, DK-1350 Copenhagen, Denmark

* Corresponding author. Email: tine.missiaen@ugent.be

Manuscript received: 7 0ctober 2015, accepted: 13 June 2016

\section{Abstract}

This paper describes the landscape evolution of the Waasland Scheldt polders in the north of Belgium from the Late Glacial - early Holocene to the present time, and the effects of this changing landscape on the human settlement. The regional landscape evolution has been visualised in a series of palaeogeographical maps for successive time frames. Two different map series were produced: a series of Holocene palaeogeographical reconstructions (11,000-950 cal BP) based on geotechnical, geological and archaeological data, and a series of post-Medieval landscape reconstructions (16th- to 19th-century) based on historical maps, land registers and soil data. Additional palaeoenvironmental information from fossil pollen and plant remains allowed reconstruction of the vegetation and wetland changes, particularly for the middle to late Holocene. Peat growth was the main key to understanding the landscape evolution of the Waasland Scheldt polders. Whereas the landscape evolution during the Holocene was mainly sea-level driven, the transformation of the landscape during the last millennium was largely due to human interventions.

Keywords: historical maps, palaeogeography, peat growth, Scheldt estuary

\section{Introduction}

The significance of coastal and estuarine areas for understanding former human life and palaeolandscapes is now recognised internationally. For example, in the context of present-day climate warming and sea-level rise, the study of the response of coastal and estuarine palaeolandscapes to postglacial sea-level rise is particularly relevant (e.g. Boski et al., 2002; Woodruff et al., 2013). The large preservation potential of these sedimentary environments, on the transition of the terrestrial and marine environment, makes them ideal for studying landscape evolution through time. Research into the intertidal area of the Severn Estuary, SW England (Bell, 2007), for instance, has provided the first human Mesolithic footprints, while in Roman and medieval times these dynamic estuarine landscapes were intensively exploited (Rippon, 2000). In Romney Marsh in SE England, one of the largest coastal wetlands in Britain, research has allowed reconstruction of the landscape evolution and human exploitation from later prehistory to the medieval period (Rippon, 2002). In the Netherlands many studies have been carried out in coastal and estuarine/fluvial wetlands, ranging from Zeeland in the southwest to the Wadden Sea area in the north, unravelling the geographical, morphological and environmental changes of these landscapes through time and the impact on human occupation (e.g. Van der Spek \& Beets, 1992; Vos \& de Wolf, 1993; Vos \& van Heeringen, 1997; Bos et al., 2005; Hijma \& Cohen, 2011; Vos \& Knol, 2015; Vos et al. 2015).

In Flanders, systematic Quaternary geological, sedimentological and palaeoecological research on fluvial and coastal wetlands has been carried out for a number of decades (e.g. De 
Muynck, 1976; Augustyn, 1977, 1985; Baeteman \& Verbruggen, 1979; Heyse \& De Moor, 1979; Baeteman 1991, 1999; Denys, 1993), and many geomorphological, geological and soil maps have been made of Belgium including its wetlands (e.g. Jacobs et al., 1993, 2010; De Moor \& van de Velde, 1995; Bogemans 1997; AGIV, 2000; Adams et al., 2002). Moreover, early reconstructions of the historical landscape of the Scheldt polders started in the 1960s (e.g. Snacken, 1964; Mijs, 1973; Guns, 1975), and research on Late Pleistocene and Holocene deposits has been carried out here since the late 1980s (e.g. Meire \& Kuijken, 1988; Kiden, 1989; Verbruggen et al., 1996; Kiden \& Verbruggen, 2001). However, systematic geoarchaeological research into onshore wetlands in Flanders is quite a recent development. Large-scale interdisciplinary wetland research in the Scheldt floodplain was often conducted in anticipation of large infrastructural works such as Antwerp harbour expansion (e.g. Minnaert \& Verbruggen, 1986; Gelorini et al. 2003, 2006; Perdaen et al. 2004; Crombé, 2005; Deforce et al. 2005; Meersschaert et al. 2006; Deforce, 2011), nature development and water management projects (Bogemans et al., 2012; Meylemans et al., 2013).

Drilling techniques for mapping and assessing the buried archaeological and palaeoenvironmental heritage were applied in Flanders for the first time in the mid-1990s, for example in the Verrebroek dock in the Scheldt polders (Crombé \& Meganck, 1996). Since then further testing mainly in the Scheldt floodplain and polders has resulted in more refined drilling techniques and methods (e.g. Bats, 2007; Crombé \& Verhegge, 2015). Recently, a new step forward was taken in prehistoric landscape reconstruction for archaeological purposes with the PhD research by Verhegge (2015). He developed an efficient approach based on near-surface geophysical and geotechnical techniques to map the prehistoric landscape of the Scheldt polders, and modelled the peat growth and the subsequent drowning of the landscape. However, his research only focused on a small test area (Doelpolder Noord), and a broader regional approach was still lacking. A second new development was the reconstruction of intertidal landscape response since the 16th century by Jongepier et al. (2015a, b). Previously this had only been attempted on short timescales, mostly less than 100 years. Using a combination of historical maps and analysis of presentday soil texture this allowed mapping of the step-wise evolution (location of tidal channels, tidal flats and salt marshes) over the last c. 400 years of the Waasland Scheldt polders marked by de- and re-embankment (Jongepier et al., 2015b).

The Waasland Scheldt polders were selected as the study area for three reasons. First, they are known to be rich in wellpreserved prehistoric sites and landscapes, as demonstrated by recent research (e.g. Crombé, 2005). Covered by 1-4 m of clayey and peaty deposits lies a well-preserved palaeo coversand landscape which was mainly formed near the end of the latest Ice Age; within this palaeolandscape many prehistoric camp sites have been discovered. Gradually this landscape was influenced by rising groundwater due to sea-level rise, which turned the area into a continuously expanding peat marsh. A second reason was the strong intertwining of landscape and human occupation during medieval and post-medieval times, especially in view of the great inundations of the 14th-16th centuries. Both direct and indirect human interventions greatly influenced the (often very rapid) transformation of the landscape. Lastly, the Scheldt polders are under imminent threat from commercial activities. Due to the continuous expansion of Antwerp harbour, only a relatively small part of the original Waasland Scheldt polders still remains. A new dock is planned in this area within the next few years, while on both sides of the border the coastal realignment in the Hedwige and Prosper polder will affect the last relicts of this drowned landscape, for example through local erosion of channels, but most of the area will be further covered and preserved under new estuarine deposits.

The main objective of this paper is to map the palaeolandscape evolution of the Waasland Scheldt polders from the Late Glacial - early Holocene to the present time. This is done on two different timescales: (1) a Holocene timescale, resulting in a series of palaeogeographical reconstructions mainly based on geotechnical, geological and archaeological data; and (2) a post-medieval timescale, resulting in a series of landscape reconstructions mainly based on historical maps, land registers and data of the soil mapping. Where possible, palaeolandscape reconstructions are also included, based on various environmental data (pollen analyses, plant remains, etc.). By combining these different techniques and methodologies we were able to obtain a coherent picture of the drowning of the dynamic landscape of the Waasland Scheldt polders since the Late Glacial, and the effects of this drowning on the successive stages of human settlement and land-use through time.

\section{Study area}

\section{General background}

The Waasland Scheldt polders consist of a flat, low-lying region on the western bank of the river Scheldt, in NW Belgium (Fig. 1). The western and eastern limits of the study area are respectively formed by the Dutch/Belgian border and the river Scheldt, with its southern limit situated at the edge of the Waasland subcuesta. The current landscape of the Waasland Scheldt polders is highly influenced by the proximity of the North Sea and the river Scheldt. The delicate balance between sea-level rise, tidal regime and river sedimentation during the Holocene resulted in different transgressive and regressive events. Adding to this since the Middle Ages, the impact of man on the landscape has become dominant by the building of dikes and rebuilding after sporadic inundations. This battle between man and water left many traces still visible in the landscape. 


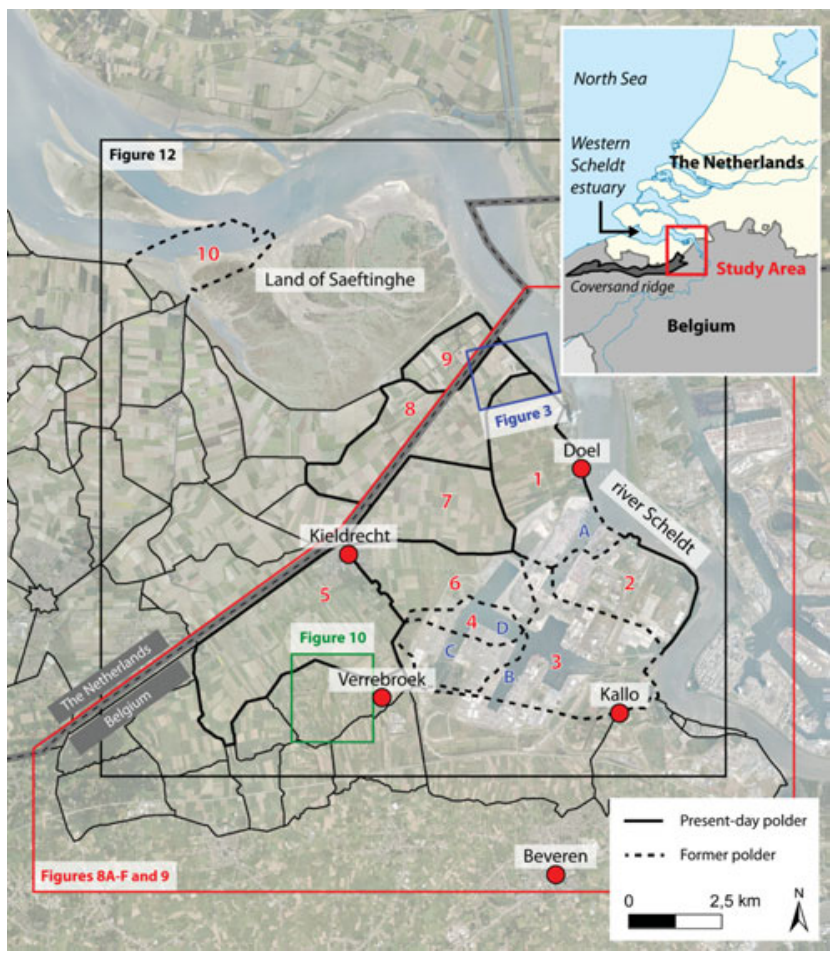

Fig. 1. Overview of the Waasland Scheldt polders in northern Belgium (background map from Google Earth(C)). The red and black boxes indicate respectively the extent of the Holocene (Fig. 8) and the post-medieval maps (Fig. 12). Blue and green boxes mark the extent of Figures 3 and 10. The grey dashed line marks the border between Belgium and the Netherlands. Full and dashed black lines respectively mark existing and former dikes. Numbers and letters refer to sites (polders and docks) discussed in the text. 1 = Doelpolder; 2 = Sint-Annapolder; $3=$ Kallopolder; $4=$ Polder van Haendorp; $5=$ Konings-Kieldrechtpolder; $6=$ Oud-Arenbergpolder; $7=$ Nieuw-Arenbergpolder; $8=$ Prosperpolder; $9=$ Hedwigepolder; $10=$ Polder van Namen; $A=$ Deurganck dock; $B=$ Vrasene dock; $C=$ Verrebroek dock; $D=$ Waasland dock.

The present-day Western Scheldt forms the southern part of the Rhine-Meuse-Scheldt region, and evolved from the Honte tidal basin during the Middle Ages (Vos \& van Heeringen, 1997; De Brouwer et al., 2001). Just north of the Waasland Scheldt polders lies the only remaining extensive tidal flat in the Western Scheldt, the (Drowned) Land of Saeftinghe (Fig. 1). It consists of approximately 3000 ha of salt marshes, mudflats and sand flats, cut by numerous tidal channels and creeks (e.g. Dijkema et al., 1984; Meire \& Kuijken, 1988; Missiaen et al., 2008; Wang \& Temmerman, 2013).

The present surface elevation in the Waasland Scheldt polders varies roughly between c. 0.5 and $6 \mathrm{~m}$ TAW (Belgian datum approximate to lowest astronomical tide (LAT) at 0stend) (see Fig. 2). This implies that the majority of this region would be flooded (sometimes even at low tide) in the absence of dikes. In the Early Middle Ages (AD 500-1000) this region was a peaty wetland environment that progressively changed into dry (oc- cupied) land due to human-induced drainage and also (at a later stage) the creation of polders (Snacken, 1964; Mijs, 1973; Augustyn, 1977; Soens, 2013). The low altitude of the land is largely the result of the drainage of the peat (in addition to peat extraction) with subsequent subsidence of the land. The lowest altitudes are often related to old creeks, that either still contain water or have dried up. In general the younger polders have a higher elevation as they silted up during a longer period of time and land subsidence started later (De Kraker, 2006; Jongepier et al., 2015b; Vos, 2015). Due to the continuous expansion of Antwerp harbour the polder landscape is only in parts preserved. The construction of large docks and adjacent industrial areas locally increased the original elevation by up to $10 \mathrm{~m}$ (see Fig. 2).

\section{Evolution of the river Scheldt}

At the end of the last glacial (c. 30-14.5 ka cal BP) the river Scheldt formed part of a braided river system that drained through the wide Flemish valley towards the west and north (Kiden \& Verbruggen, 2001). The braided rivers were marked by wide, but shallow, mostly sandy river channels with seasonally variable water levels (Kiden \& Verbruggen, 2001; Kiden, 2006). The sparse tundra vegetation cover created a surface extremely susceptible to wind erosion (Verbruggen et al., 1996) which led to the formation of local coversand ridges (Heyse \& De Moor, 1979), a process which continued during the cold Dryas stadials of the Late Glacial (Crombé et al., 2012). One of these coversand ridges, the Maldegem-Stekene ridge (3-4 m high and 2-3 km wide; see inset Fig. 1), gradually dammed the Flemish Valley, forcing the rivers to follow a new course (Kiden, 1991; Kiden \& Verbruggen, 2001; Crombé et al., 2013). (This coversand ridge ran over a much larger distance than its name seems to suggest: from the North Sea coast (Gistel) to the Waasland Scheldt polders (Verrebroek) (see Fig. 1).) Also the river Scheldt established a new (eastern) route, breaching through the cuesta near Antwerp, possibly using an existing depression in the cuesta (Kiden, 1991), towards the Rhine-Meuse valley.

Rising temperatures during the Late Glacial (14.5-11.5 ka cal BP) caused major hydrological changes, affecting the discharge, regime and sediment load of the river systems (Kiden, 1991; Verbruggen etal., 1996; Bogemans et al., 2012; Crombé et al., 2013; Meylemans et al., 2013). The braided pattern of the river Scheldt changed into a large-scale meandering pattern, incising the previously infilled Pleistocene topography (Verbruggen et al., 1991; De Moor \& van de Velde, 1995; Bogemans, 1997). At the start of the Holocene (c. $11.5 \mathrm{ka}$ cal BP) climatic warming resulted in an increasingly dense vegetation cover, decreasing the river discharge and sediment transport (Kiden \& Verbruggen, 2001). At this time the river Scheldt still drained towards the north into the Rijn/Maas valley (Vos \& van Heeringen, 1997). 


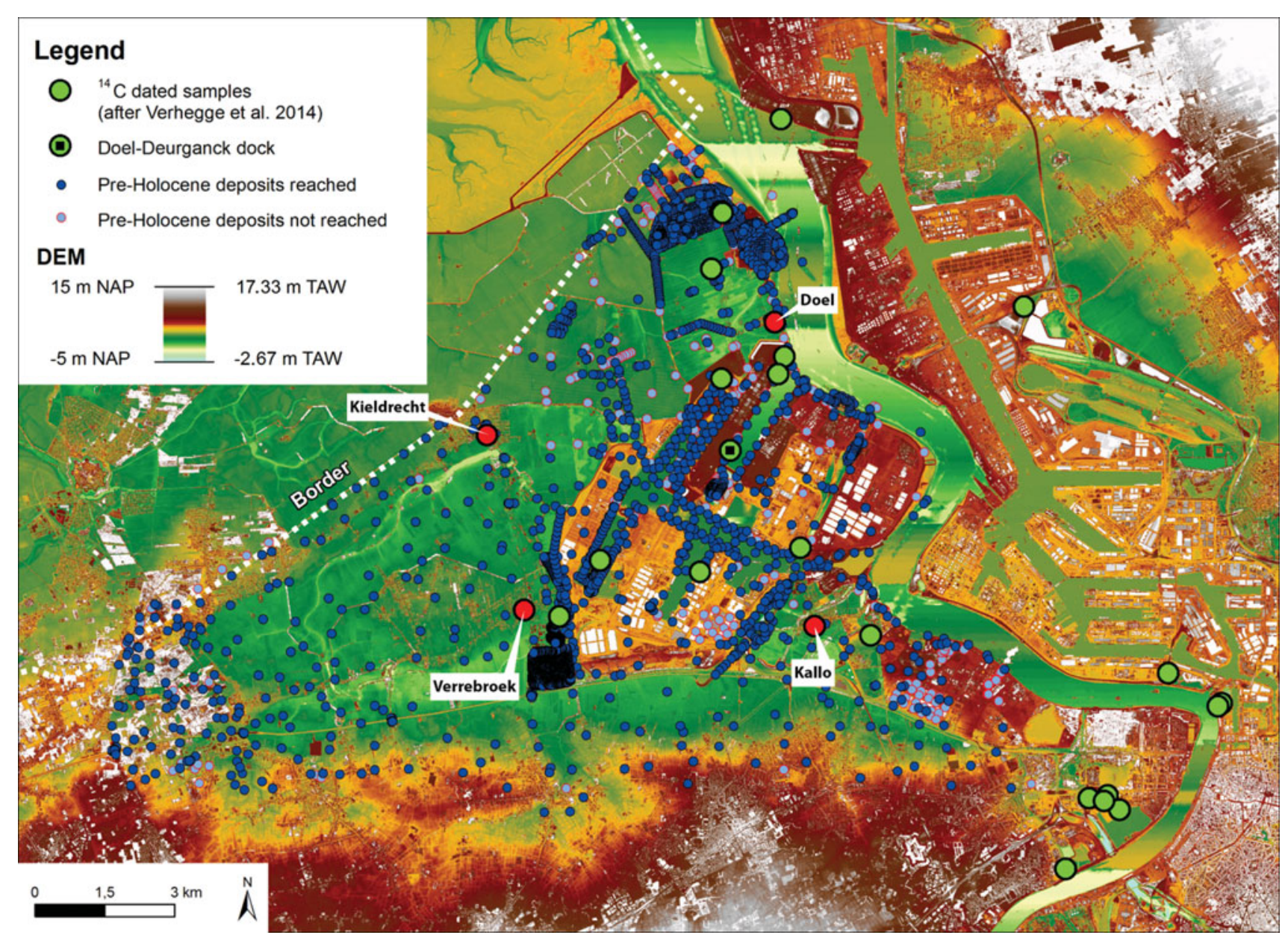

Fig. 2. Distribution of data used to reconstruct the Holocene evolution of the Waasland Scheldt polders (each dot represents a sediment core, archaeological augering or (PT). Background elevation data (in $m$ NAP and TAW) from AGIV (Agentschap voor geografische informatie Vlaanderen) (c). Dark blue dots indicate data points that reach the pre-Holocene deposits. Light blue dots indicate data points that were too shallow to reach the top of the Pleistocene deposits. Green dots indicate locations of ${ }^{14} \mathrm{C}$ samples (after Verhegge et al., 2014). The black rectangle indicates the location of the peat/clay sequence at Doel-Deurganck dock that was used for multi-proxy palaeoenvironmental analysis. The white dashed line marks the border between Belgium and the Netherlands.

Around 7400-6300 cal BP the river Scheldt established a new northwesterly route towards the North Sea through the Eastern Scheldt (Oosterschelde) (Kiden, 2006). This change of the river's position and the further rising sea level caused the Lower Scheldt to turn brackish and to experience tidal influence; it is the furthest marine incursion for the Lower Scheldt during the middle Holocene (Kiden, 2006). From roughly $5700 \mathrm{cal} \mathrm{BP,}$ sea-level rise started to slow down and the tidal influence in the Lower Scheldt disappeared until the Early Middle ages.

At least until the Early Middle Ages the river Scheldt discharged through the Eastern Scheldt, a peat-covered ridge northwest of the Land of Saeftinghe blocking a more western course (Van Rummelen, 1965; Vos, 2015). The connection between the Honte tidal basin (the precursor of the Western Scheldt) and the river Scheldt east of Saeftinghe most likely came into existence in the 9th century AD (Leenders, 1986; Vos \& van Heeringen, 1997). During the 11th and 12th centuries the Honte sea branch gradually enlarged, probably as a result of various floods (Gottschalk, 1984). Until the 15th century, however, the Honte connection (now called Western Scheldt) remained very shallow and navigation was only possible during high tide (Brand, 1983). Storm surges in the 15th and 16th centuries resulted in large-scale inundations and an increase in the tidal regime of the Western Scheldt. This led to a shift in the watershed between the Western and Eastern Scheldt, the Western Scheldt now becoming the main branch of the river Scheldt (van der Spek, 1994; Vos \& van Heeringen, 1997; Vos, 2015).

\section{Geological setting}

In the Waasland Scheldt polders the Quaternary deposits rest on Neogene sediments which consist largely of sandy deposits (Formations of Lillo and of Kattendijk), covering thick clay 
beds of Oligocene age (Formation of Boom (Member of Putte)) (Jacobs et al., 1993, 2010). The Quaternary deposits are less than $5 \mathrm{~m}$ thick in the southwest and increase up to a thickness of $25-30 \mathrm{~m}$ in the northeast.

The Quaternary stratigraphy of the Waasland Scheldt polders is complex, and over the years several subdivisions have been described and proposed for different areas (see De Moor \& van de Velde, 1995). The Quaternary deposits in the Waasland Scheldt polders were all deposited in a dynamic environment, implying much lateral variation within the same depositional unit. Consequently, these deposits have been catalogued into units based on the following criteria adapted from De Moor (2002): (1) the lithostratigraphy (including lateral extent), (2) the chronostratigraphy, (3) the lithology and sedimentology of the sedimentary facies, and (4) the genesis of the deposit and indications for its palaeoenvironment (see Methodology section).

The oldest Quaternary deposits in the study area are Middle Weichselian sandy river deposits. They are only observed in the eastern and extreme western part of the study area. They consist of fine to coarse river sands that were deposited by a braided river system in a periglacial environment c. 30,000 years ago De Moor \& van de Velde, 1995; Bogemans, 1997; Adams et al., 2002). In the central part of the study area Late Glacial and Holocene deposits lie directly on top of the Neogene formations.

The covering Quaternary unit consists of Late Glacial aeolian sand deposits (marine istope stage 2, c. 30-15 ka cal BP). During this period the climate was still very cold and windy, the vegetation cover was limited and a thin layer of sand (on average $2 \mathrm{~m}$ thick) was deposited over the entire Waasland Scheldt area (De Moor \& van de Velde, 1995; Bogemans, 1997; Adams et al., 2002), similar to many other regions in NW and central Europe (e.g. Kasse, 2002).

The Pleistocene coversand deposits in the Waasland Scheldt polders are locally overlain by Late Glacial / early Holocene meandering river deposits consisting of one, sometimes two, fining-upward cycles (from fine sand to silt/clay) and ranging in thickness between 2 and $5 \mathrm{~m}$ (Bogemans, 1997). In other, less energetic parts of the floodplain, clay was sometimes deposited (De Moor \& van de Velde, 1995).

The lowermost Holocene deposits consist of (dark) brown peat. Most of the basal peat accumulated in a marsh environment along the Scheldt river and estuary. With time, peat also started to grow in higher locations. The total thickness of the peat deposits ranges roughly between 0.1 and $6 \mathrm{~m}$. In the (north)eastern part of the Waasland Scheldt polders, the basal peat is covered by a grey to almost black clay (occasionally sandier), which often contains peat fragments. This sediment was deposited during the marine incursion of the middle Holocene (around $6000 \mathrm{cal}$ BP) which changed the lowlying western bank of the river Scheldt into an estuarine tidal landscape (Minnaert \& Verbruggen, 1986; Verbruggen \& Denys,
1995; Gelorini et al., 2006; Deforce, 2011; Deforce et al., 2014a). In some places this marine incursion eroded the basal peat.

The peat deposits are overlain and locally eroded by a sequence of late Holocene estuarine sandy and clayey sediments, often with remains of organic matter or marine shell fragments, that was deposited in a tidal flat environment (Kiden \& Verbruggen, 2001; Kiden, 2006). Consequently there is a lot of lateral variability within this deposit ranging from a thickness of roughly $5 \mathrm{~cm}$ up to $10 \mathrm{~m}$. The most recent sediments consist of late and post-medieval flood deposits made up of (often organic-rich) clay, which are locally more sandy towards the base.

\section{Occupational history}

The Waasland Scheldt polders are known to be rich in archaeological remains, especially dating back to prehistoric and medieval times (Crombé, 2005; Meersschaert et al., 2006). During the last decades various archaeological salvage excavations in the vicinity of Doel and Verrebroek (for location see Fig. 1), conducted in the context of harbour expansion, have revealed a number of well-preserved prehistoric settlements, all located on the tops and flanks of Upper Pleistocene sand ridges (Crombé, 2005). The oldest remains date back to the Final Palaeolithic and Early Mesolithic, when the landscape was still a largely dry environment (Crombé et al., 2011, 2013). A series of sites dating back to the Mesolithic-Neolithic transition (Crombé, 2005; Sergant et al., 2006), and attributed to the Swifterbant culture (Crombé et al., 2011), are contemporaneous with a period of increased tidal influence (Verhegge et al., 2014).

So far no direct archaeological proof of human activity has been found that dates from the Middle Neolithic to the Middle Ages, when the area was covered by large fens and peat bogs, but archaeological records from nearby locations in the southwestern Netherlands indicate that occupation took place even in these wet situations (De Clercq, 2009; De Clercq \& Van Dierendonck, 2009). For instance, near Borsele a Roman settlement was discovered on top of the peat (Sier, 2003). At Colijnsplaat in the Oosterschelde estuary and at Serooskerke, Roman occupation was attested at the top of the peat (De Clercq \& Van Dierendonck, 2009; Dijkstra \& Zuidhoff, 2011). According to Vos \& van Heeringen (1997) the oldest occupation of the peat landscape occurred along the edges of the estuarine system and can be dated back to the early Iron Age (roughly $2600 \mathrm{BP})$.

The medieval occupational history of the Waasland Scheldt polders has not been completely established so far. Historical sources inform us of a gradual intensification of land use in the 12th century, starting from the Waasland subcuesta in the south and the Pleistocene sand ridges, on which the medieval villages Kallo, Verrebroek and Kieldrecht (see Fig. 1) are mentioned from the 12th century onwards (Augustyn, 1977; Van Gerven, 1977). Saeftinghe in the north became a stronghold 
of the count of Flanders in the 13th century, controlling navigation on the river Scheldt (Gottschalk, 1984). The count of Flanders and the lord of Beveren also granted large stretches of marshlands to abbeys, which turned them into agricultural estates.

At the height of the medieval occupation phase in the 14th century, several new settlements came into existence, many of them related to peat exploitation and transport (e.g. Namen, Casuwele, Sint-Laureins) (Gottschalk, 1984). The decline of peat exploitation and increasing flood problems (a direct result of the lowering of the landscape due to peat compaction and extraction) locally intensified the general demographic and economic decline of the 14 th century. At the end of the 16th century large parts of the Waasland Scheldt polders were flooded as a result of large-scale inundations, mostly intentionally caused as part of a military strategy during the Eighty Years' War. Only the more elevated areas (e.g. the village centre of Kieldrecht and the polders of Namen, Doel and Sint-Anna) were spared the inundations. In the following centuries the area lost to the sea was gradually re-embanked and reoccupied (Jongepier et al., 2015b).

\section{Methodology}

\section{Holocene palaeogeographical maps (11,000-950 cal BP)}

The topographical and palaeogeographical maps of the Holocene were created using geological and geotechnical information from a wide variety of sources: sediment cores, cone penetrometer tests (CPT) and archaeological augerings. The vast majority of the core and CPT data were obtained from the subsurface database of the Flemish Government (Databank Ondergrond Vlaanderen - DOV). New CPT and core data were obtained in 2011-14 in Doelpolder (Verhegge et al., 2014; Missiaen et al., 2015) and near Kieldrecht and Verrebroek (for location see Fig. 1). The depth of the CPT data varied roughly between 8 and $30 \mathrm{~m}$. Geological information from archaeological augerings was provided by the Department of Archaeology of Ghent University; these data were obtained in the framework of various projects. Average depth of the augerings ranged from 2 to $7 \mathrm{~m}$ whereas core interdistance generally ranged between 3 and $50 \mathrm{~m}$ (with a few exceptions up to 70-80 m).

A major difficulty in the dataset was the diversity of the type of data (electrical and mechanical CPT, mechanical core, hand augering), the diversity in depth resolution (ranging from $1 \mathrm{~cm}$ to over $50 \mathrm{~cm}$ ), and the diversity of observers (geologists, engineers, archaeologists). Consequently not only the quality of the data varied greatly, but also the determination of the exact depth and thickness of each sediment unit.

In the final dataset, only sites with raw data available (e.g. detailed sediment descriptions or original CPT measurements) were considered. The data were interpreted following the criteria mentioned earlier ('Geological setting' section), and considering the most current geological knowledge of the area. Using the sedimentological description (e.g. clay, sand or peat), the palaeoevironmental indicators (e.g. shells or plant remains), the lithostratigraphic position, the chronostratigraphic information (if available) and the correlation with all sites in the close vicinity, all deposits were logged in different units (not necessarily present at all sites). These units consist from bottom to top of (1) a mostly sorted sandy deposit with no biological remains interpreted as a Late-Glacial coversand, (2) a clay and/or sandy clay (often absent) interpreted as an early Holocene meandering river and/or river flood deposit, (3) a (dark) brown peat sometimes intercalated by a clay layer which is interpreted as a peat deposit interrupted by a marine incursion, (4) a sequence of sand and clay deposits with shell remains interpreted as Late Holocene estuarine deposits, (5) an anthropogenic clay interpreted as late and post-Medieval flood deposits, and (6) a soil cover and/or construction deposits related to harbour activities.

The majority of the CPT data involved mechanical CPT measurements. Resolution of the mechanical and electrical CPT data was respectively $10-20 \mathrm{~cm}$ and $2-5 \mathrm{~cm}$. It is known that the accuracy of mechanical CPT data can sometimes be inadequate for a quantitative analysis (Lunne et al., 1997), and interpretation was therefore done with great care, and where possible also comparing with sediment cores taken in close proximity. Electrical CPT logs are generally better suited to determine the different stratigraphical layers but also here the interpretation was done manually and involved a good local geological knowledge. Automated classification of soil stratigraphy was abandoned since this often did not allow the peat and (organic-rich) clay layers to be distinguished (Missiaen et al., 2015).

In total the dataset consisted of 6423 data inputs of which 5783 reached the Pleistocene/Holocene boundary (Fig. 2). However, not all these data could be used to deduce a detailed Holocene stratigraphy. Notwithstanding the careful data interpretation, most of the mechanical logs only allowed the transition from soft Holocene sediment to more compact sandy Pleistocene sediment to be deduced. With regard to core data, only cores with a detailed sediment description could be used. As can be seen in Figure 2, the data coverage is not evenly distributed. In areas of archaeological interest or with a lot of construction works (e.g. docks of Antwerp harbour) the data density is very high. In the agricultural parts of the study area data are scarcer, and the data description is often less detailed.

The distinction between late Holocene estuarine (clay) deposits and overlying late to post-medieval flood deposits was not always straightforward. For the cores the main criterion was the presence of organic material and human traces (in which case we speak of flood deposits, labelled as 'polder clay' by 
DOV). For the CPTs the main criterion was the friction ratio $\left(R_{\mathrm{f}}\right)$ which was often noticeably lower in the estuarine sediments. The distinction between early Holocene river clay deposits and overlying Mid-Holocene marine clay (in the absence of a lower peat layer) was based on colour and the presence of marine shell fragments.

To allow optimal integration with data from the Netherlands, and an easier comparison with relative mean sea-level curve reconstructions, all depths were converted from the Belgian reference level (TAW) to the Dutch reference level (NAP). In practice this meant subtracting $2.33 \mathrm{~m}$ from every depth or elevation.

\section{Post-medieval landscape maps (AD 1570-1850)}

For the landscape reconstructions of the post-medieval period, historical maps were the main source of information. The excessively large map production in the Waasland Scheldt polders (a direct result of land-surveying practices related to large embankment works) makes historical maps a source for landscape evolution studies that can hardly be overlooked. The analysed maps were selected from a database of around 300 historical maps (16th- to 19th-century) found in the (State) Archives of Brussels, Ghent, Beveren and Middelburg.

Although they provide a rich source of information, historical maps have some serious limitations. Quality and accuracy may vary widely between different maps, leading to misinterpretations in the palaeolandscape reconstruction when using these maps without regarding these limitations. A vital component of the quality and usefulness of historical maps is the planimetric accuracy, or how well distances and locations on these maps correspond to the actual distances and locations of corresponding (present-day) features. Knowing this accuracy, it is possible to evaluate the likelihood that a reconstruction will accurately display the former area.

Recently a methodology was developed by Jongepier et al. (2015a) that allows one to calculate, analyse and visualise the planimetric accuracy of historical maps. For the present study we have applied this methodology to evaluate the planimetric accuracy of 30 historical maps covering the Waasland Scheldt polder area. As one might expect, supraregional (smallscale, i.e. $>1000 \mathrm{~km}^{2}$ ) maps generally showed the lowest accuracy, with mean positional errors (MPEs) between 500 and $1600 \mathrm{~m}$, making their use for palaeolandscape reconstruction very restricted. Regional (medium-scale, i.e. 100-1000 km²) maps proved to be far more accurate, often becoming more accurate over time, although a large variation was noticeable here. Local (large-scale, i.e. $<100 \mathrm{~km}^{2}$ ) maps provided the highest planimetric accuracy, with MPEs of $<50 \mathrm{~m}$, and also provided enough topographical details (especially when the maps were related to embankment activities). Surprisingly, however, the quality of older maps (16th- or 17th-century) could be as high as or even higher than more recent maps. This was certainly the case for large-scale maps, but even medium- and smallscale maps showed rather weak correlations between date and positional accuracy (Jongepier et al., 2015a).

Based on the dates of (re-)embankments and inundations in the region, five time slices were chosen in order to conduct a landscape analysis of the Waasland Scheldt polders (respectively AD 1570, 1620, 1690, 1790 and 1850) (Jongepier et al., 2015b). For each time slice, several maps were georeferenced and digitised in GIS. Choosing the most appropriate map(s) for each reconstruction was largely based on the positional error, since a small error would, at least in theory, provide the most accurate depiction of that area (Fig. 3). In addition to this quantitative approach, the qualitative interpretation also played an important role, such as topographical detail and date (Jongepier et al. 2015a). In view of the importance of the Saeftinghe area with respect to the post-medieval landscape evolution of the Waasland Scheldt polders, this area was included for the reconstructions.

Appropriate maps for the late medieval period are not abundant (the older the map, the smaller the chance of conservation). Furthermore, detailed local and regional maps have only been produced in large quantities from the 17th century onwards. The map of 1575 made by land surveyor F. Horenbault (Rijksarchief Gent, Kaarten \& Plans, no. 2454), showing the impact of late medieval small-scale inundations, proved to be the most suitable for the 1570 reconstruction. Mean positional error of this map was $722 \mathrm{~m}$.

For the 1625 reconstruction the 'map by Coeck' (Atlas van Loon, Scheepvaartmuseum Amsterdam) proved very valuable, showing the inundations of the late 16th century and the first re-embankments in the south of the Waasland Scheldt polders in great detail. Though the geometric accuracy of this map is limited $(1383 \mathrm{~m})$, elaborate georeferencing resulted in a useful depiction of the salt marsh. Moreover it makes a clear division between the higher and lower salt marsh. The map probably dates to around 1625 .

By the late 17th century an increasing number of highly detailed large-scale maps were made. For the 1690 reconstruction, two high-quality local maps (Atlas of Hattinga, Zeeuws Archive Middelburg) proved very valuable for the southwestern and eastern part of the study area. Mean positional errors were mostly outstanding (as low as $53 \mathrm{~m}$ ), though correct assessment of the MPE in certain embankment areas was not always possible due to lack of correspondance with the actual landscape (since the entire embankment was drowned later). The reconstruction in the remaining parts of the study area was based on two supraregional maps with a MPE of 1006 and $1507 \mathrm{~m}$.

For the reconstruction of 1790 a large number of highquality maps were available. A good example is the local map by land surveyor J. Coppens which shows the eastern salt marsh near the Doelpolder and on which perpendicular distances from the dikes to the border of the higher salt marsh were also 

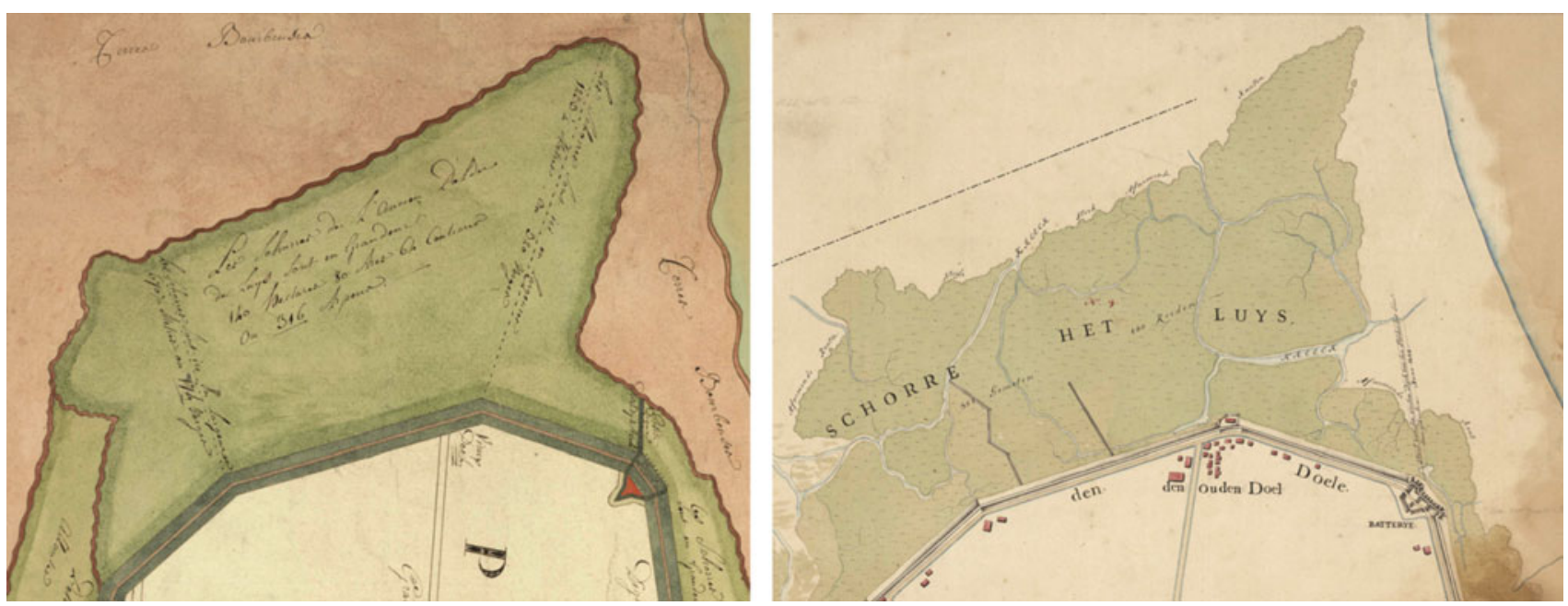

Fig. 3. Two maps depicting the same part of a salt marsh near Doel (for location see Fig. 1). Left a map from 1813 (ARA, Arenberg, no. 842) with a mean positional error (MPE) of $104 \mathrm{~m}$, right a map from 1816 (ARA, Kaarten \& plans, no. 8554) with a MPE of $33 \mathrm{~m}$. The map on the right with the lowest MPE is to be preferred, on condition that the date of the map corresponds with the chosen time period.

indicated. This resulted in an excellent mean positional error of $103 \mathrm{~m}$. The reconstruction of 1850 was based on several largescale maps, produced in large series. For the Dutch parts of the reconstruction, the 'Bonnebladen' of Sealand were available. For the Belgian parts, the first cadastral surveys (Primitive Cadastral maps/Maps of P.C. Popp) proved to be the most useful.

\section{Palaeoecological data}

The value of traditional landscape-related biological proxies (e.g. fossil pollen, phytoliths, charcoal and plant macrofossils) has been demonstrated in the palaeoenvironmental study of natural sediment archives and archaeological features worldwide (e.g. Nelle et al., 2010; Mayle and Iriarte, 2014; Mercuri et al., 2014; Mauri et al., 2015). These proxies have been proven to be powerful tools that help elucidate past environmental and climatic conditions and human responses to changing ecosystem services (Birks \& Birks, 2006; Nelle et al., 2010; Birks et al., 2014). To ensure an accurate palaeogeographical reconstruction, we therefore also integrated relevant information from landscape-related proxy data (mainly fossil pollen, charcoal and plant macrofossils) derived from palaeo-soils, peat deposits and archaeological features in the study area. The contemporaneity and comparability of these data enabled a reconstruction of the vegetation composition and wetland changes particularly from the middle to late Holocene. Contrarily, proxy data recorded from sediment archives dating from the Late Glacial to the early Holocene were far less abundant and more subjected to taphonomical and/or interpretative constraints. Figure 2 shows an overview of the sampling locations for radiocarbon dates on bulk peat samples and small terrestrial peat macro-remains (cf. Verhegge et al., 2014).
In the framework of this study, a $1 \mathrm{~m}$ thick peat/clay sequence from Doel-Deurganck dock (for location see Fig. 2) was selected for multi-proxy, palaeoenvironmental analysis. The selection of this site was based on the fact that it represents one of the rare peat beds located relatively far inland that contain marine transgressive deposits - all the other studied peat sequences in the Waasland polders being very close to the Scheldt river. The sequence from Doel-Deurganck dock therefore allows more insight to be gained into the vegetation shift related to the marine transgression further away from the estuary. In order to reconstruct local vegetation and hydrological changes during the middle Holocene, palynomorphs, diatoms and sedimentological properties were analysed. Loss on ignition (LOI) (Bengtsson \& Enell, 1986) was applied at $3 \mathrm{~cm}$ intervals across the sediment units to estimate the amount of minerogenic and organic sediment input.

A total of 17 sediment samples at varying $3 \mathrm{~cm}$ (peat, in situ) and $10 \mathrm{~cm}$ (organic clay, allochthonous) intervals were prepared following standard pollen-analytical procedures (Moore et al., 1991). In each sample, palynomorph counting continued until at least c. 500 terrestrial pollen grains were encountered to ensure statistical robustness of the results. However, in four samples palynomorphs were almost completely absent (see Fig. 4, marked with $\mathrm{x}$ ) and, hence, disregarded for further analysis and interpretation. Since diatoms are not well preserved and mostly absent in peaty deposits (e.g. Gelorini et al., 2006), only samples (11 in total, $5 \mathrm{~cm}$ interval) from the clayey deposit were taken for in-depth analysis in order to provide additional insights into palaeohydrological conditions and possible tidal forcing. Terrestrial plant remains from the base of the two peaty units and top of the lower peaty unit (basal peat) were selected for accelerator mass spectrometry (AMS) ${ }^{14} \mathrm{C}$ dating (see Table 1). 
Table 1. Details of the radiocarbon dates from the peat/clay sequence from Doel-Deurganck dock.

\begin{tabular}{|c|c|c|c|c|c|c|c|c|c|c|}
\hline Lab no. & $\begin{array}{l}\text { Uncal } \\
\text { BP }\end{array}$ & $\begin{array}{l}\text { Standard } \\
\text { deviation }\end{array}$ & $\delta^{13} \mathrm{C}(\%)$ & $\begin{array}{l}\text { Sample } \\
\text { composition }\end{array}$ & $\begin{array}{l}\text { Stratigraphic } \\
\text { position }\end{array}$ & Lat. & Long. & $\begin{array}{l}\text { Elevation } \\
\text { (m NAP) }\end{array}$ & $\begin{array}{l}\text { Cal BP } 1 \\
\text { sigma }\end{array}$ & $\begin{array}{l}\text { Cal BP } 2 \\
\text { sigma }\end{array}$ \\
\hline RICH-20092 & 6269 & 37 & -26.6 & charcoal & $\begin{array}{c}\text { basis of basal } \\
\text { peat layer }\end{array}$ & $51^{\circ} 17^{\prime} 10.7^{\prime \prime}$ & $4^{\circ} 15^{\prime} 01.5^{\prime \prime}$ & -3.95 & $7250-7170$ & $7280-7020$ \\
\hline RICH-20091 & 5477 & 42 & -23.9 & Urtica dioica & $\begin{array}{l}\text { top of basal } \\
\text { peat layer }\end{array}$ & $51^{\circ} 17^{\prime} 10.7^{\prime \prime}$ & $4^{\circ} 15^{\prime} 01.5^{\prime \prime}$ & -3.67 & $6310-6215$ & $6400-6190$ \\
\hline RICH-20093 & 4856 & 36 & -26.8 & $\begin{array}{l}\text { Urtica dioica; } \\
\text { wood }\end{array}$ & $\begin{array}{c}\text { basis of upper } \\
\text { peat layer }\end{array}$ & $51^{\circ} 17^{\prime} 10.7^{\prime \prime}$ & $4^{\circ} 15^{\prime} 01.5^{\prime \prime}$ & -3.12 & $5650-5580$ & $5660-5480$ \\
\hline
\end{tabular}

Calibrated according to Reimer et al. (2013).

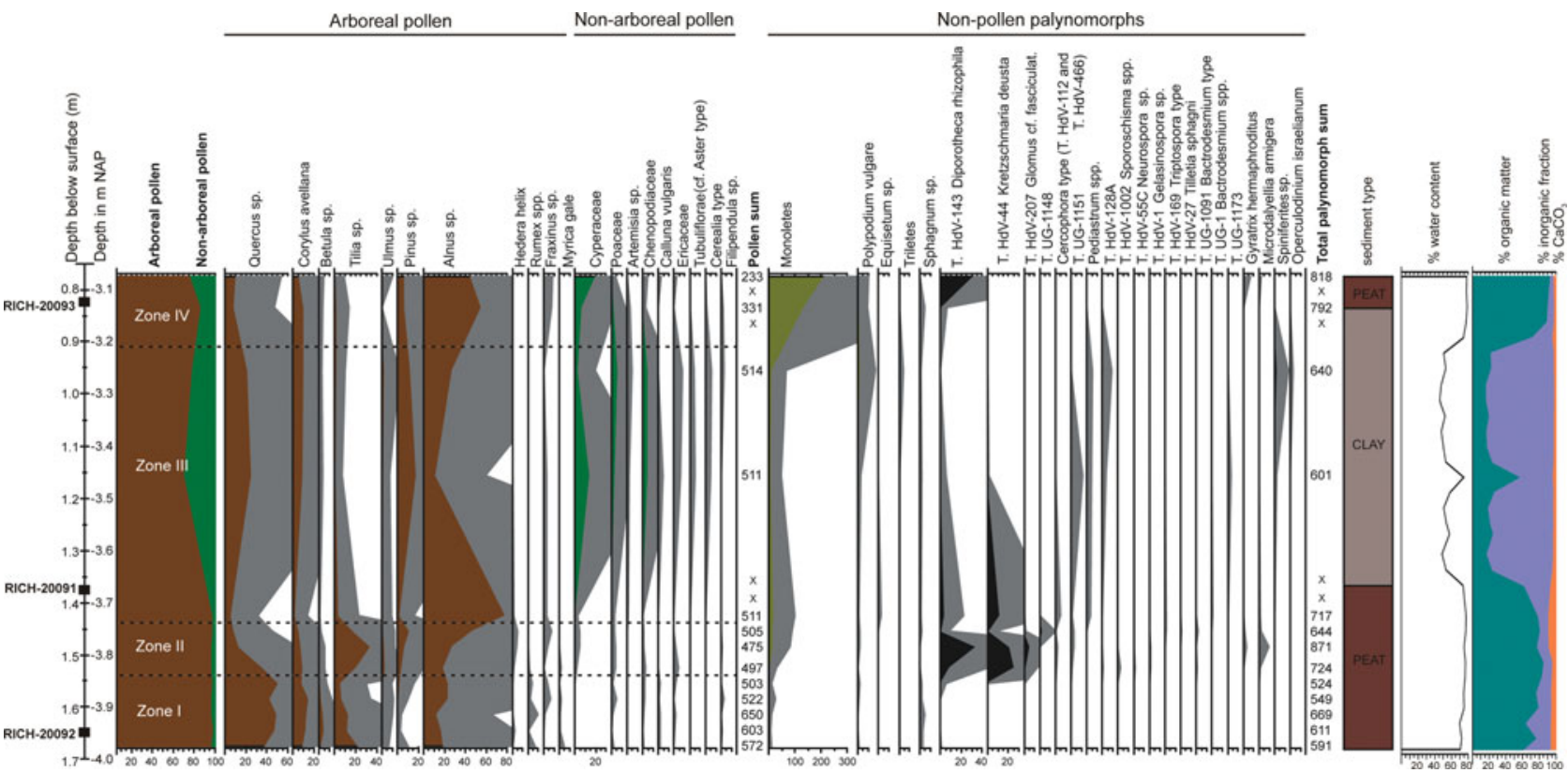

Fig. 4. Pollen percentage and loss on ignition (LOI) diagram from Doel-Deurganck dock (for location see Fig. 1). Shaded graphs present 10x exaggeration of original percentages.

\section{Palaeogeographical base map and Holocene time frame}

Correct reconstruction of the Holocene palaeogeography requires a reliable model of the Pleistocene surface relief. An isohypse map of the boundary surface was constructed using both geostatistical software and geological interpretation. As a first step an empirical semi-variogram was calculated using the 5783 data points that reached the Pleistocene-Holocene boundary. Based on the best-fit model (in our case a directional linear semi-variogram with a nugget of 0.7 ) and using point kriging, a grid for the boundary surface was then created (XY spacing $40 \mathrm{~m}$, minimum eight data points per grid cell). In order to minimise any local artefacts (e.g. oval depressions instead of valleys, or a higher relief than the current relief) a combination of the gridded surface, the original data points, the digital elevation model (DEM) and general geological knowledge of the area were used to draw the final Pleistocene-Holocene boundary relief map by hand using ArcGIS (Fig. 5).
The thus created Pleistocene-Holocene boundary map reflects the original palaeorelief only when the (basal) peat is still present in the subsurface. When the basal peat has been eroded, assumptions about the Pleistocene surface have to be made using a good geological knowledge of the area and of the depositional environments. In the Waasland Scheldt polders peat was present everywhere, except for two small channels southwest of Kieldrecht (black arrows in Fig. 5) which are linked to marine incursions due to breaching of the embankments. The current relief of the Pleistocene-Holocene boundary surface could be considered the palaeosurface. As can be seen in Figure 5 the southern and southwestern part of the Waasland Scheldt polders, where the coversand locally almost reaches the surface, is marked by a higher palaeotopography (above $0 \mathrm{~m} \mathrm{NAP}$ or $2.33 \mathrm{~m}$ TAW), while the northeastern part is lower (below $0 \mathrm{~m} \mathrm{NAP}$ ) and here the Holocene cover is much thicker. This topography fitted very well with the Pleistocene/Holocene surface of the Netherlands, though the latter generally showed less detail due to the different scale 


\section{LEGEND}

\section{Top Pleistocene (m NAP)}

\begin{tabular}{|c|c|c|}
\hline$<-9$ & $-2--3$ & $4-5$ \\
\hline$-8--9$ & $-1--2$ & $5-6$ \\
\hline$-7--8$ & $0--1$ & $6-7$ \\
\hline$-6--7$ & $0-1$ & $7-8$ \\
\hline$-5--6$ & $1-2$ & $8-9$ \\
\hline$-4--5$ & $2-3$ & $>9$ \\
\hline$-3--4$ & $3-4$ & \\
\hline
\end{tabular}

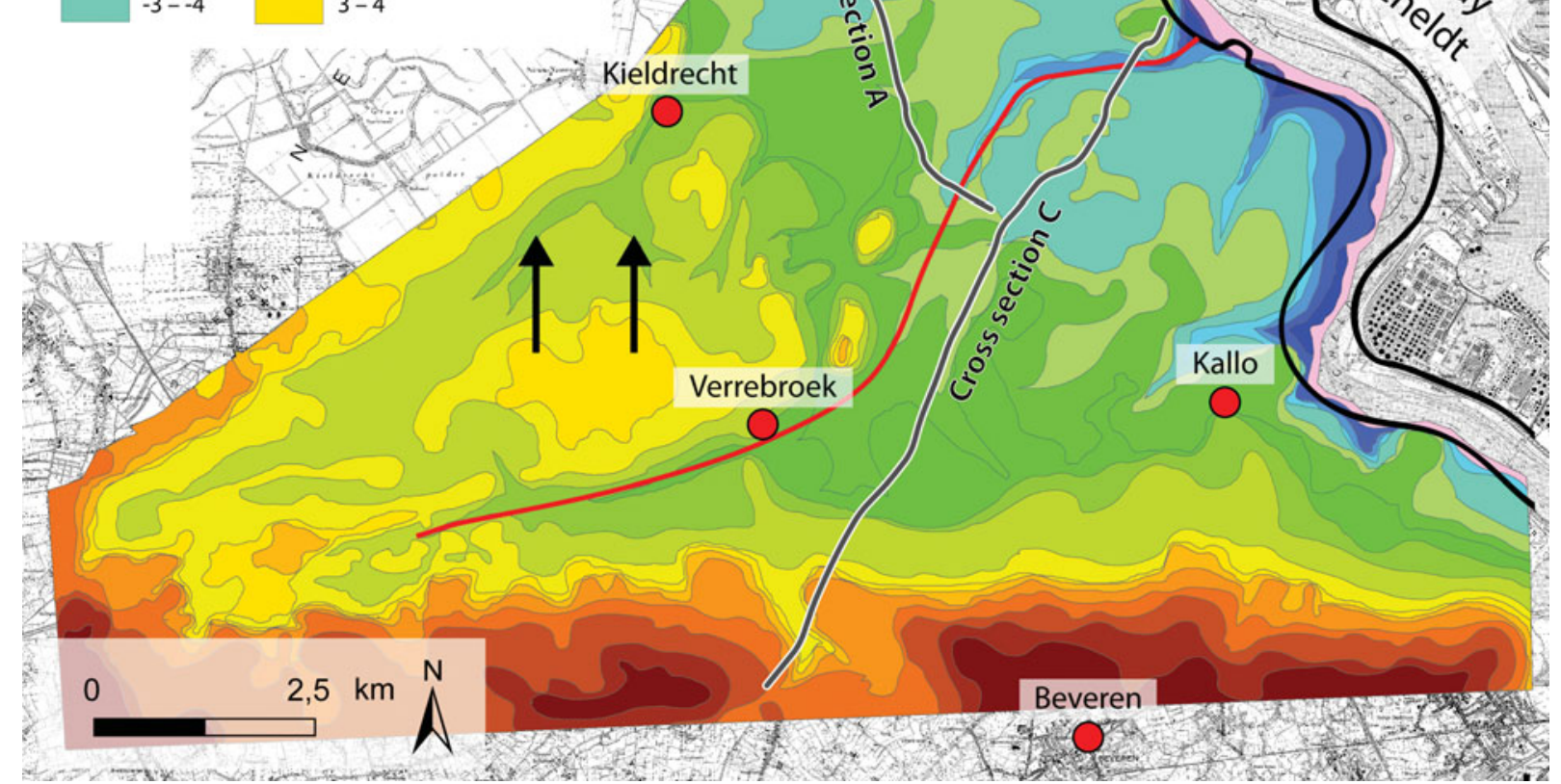

Fig. 5. Final relief map of the top of the Pleistocene deposits (i.e. Pleistocene-Holocene boundary) based on point data, gridded data, digital elevation model and general geological knowledge. Elevation in $m$ NAP (Dutch reference level). The red line marks a possible valley system that shows a strong link with prehistoric occupation (cf. Fig. $8 A$ ). Thick grey lines mark the location of cross-sections $A$ to $C$ shown in Figure 7 . The black arrows mark two small channels SW of Kieldrecht where the basal peat has been eroded.

of the study (after Vos \& van Heeringen, 1997; Vos et al., 2002).

Using the Pleistocene surface relief, together with the Holocene stratigraphy, different palaeoenvironmental maps for successive time slices could be created. The elevation of the Pleistocene surface was used to determine the maximum extent of the (Holocene) marine deposits and peat deposits. In order to obtain a time frame for the reconstructions, relative sea-level curves for Belgium and the S(W) Netherlands (Denys \& Baeteman, 1995; Kiden, 1995, 2006) and a dated peat growth evolution model for the Waasland Scheldt polders (Verhegge etal., 2014) were used as they provide an age for the altitude to which the marine influence was present or show how the peat expanded (Fig. 6). For the peat growth model, a series of radiocarbon dates from organic remains (i.e. seeds/fruits and charcoal) was collected at the base of the peat deposits at different heights (for the sample locations see Fig. 2). Considering the error margins in the semi-variogram calculation (error variance of $2.5 \mathrm{~m}$ ) and the point kriging of the model of the
Pleistocene surface relief, the maps do not always follow the model of Verhegge et al. (2014) to the letter.

In order to visualise the extent and variability of the Holocene deposits three cross-sections were made that cover various parts of the study area (for their location see Fig. 5). The cross-sections were created in areas with sufficient density of high-quality core or CPT data to allow good correlation without much interpolation. In the first cross-section (Fig. 7A) parallel to the river Scheldt the earliest Holocene deposits (meandering river deposits) are present in a small depression cut into the surface of the top of the Pleistocene deposits. The young (1000 years old and younger) estuarine deposits are vertically and horizontally variable, locally eroding the underlying peat. In the second, short cross-section (Fig. 7B) through the northern part of Doelpolder close to the river Scheldt the thick layer of marine deposits in between the peat deposit stands out clearly. In the third, long cross-section (Fig. 7C) perpendicular to the river Scheldt and crossing the harbour area we see the different sedimentary environments in the Holocene deposits 

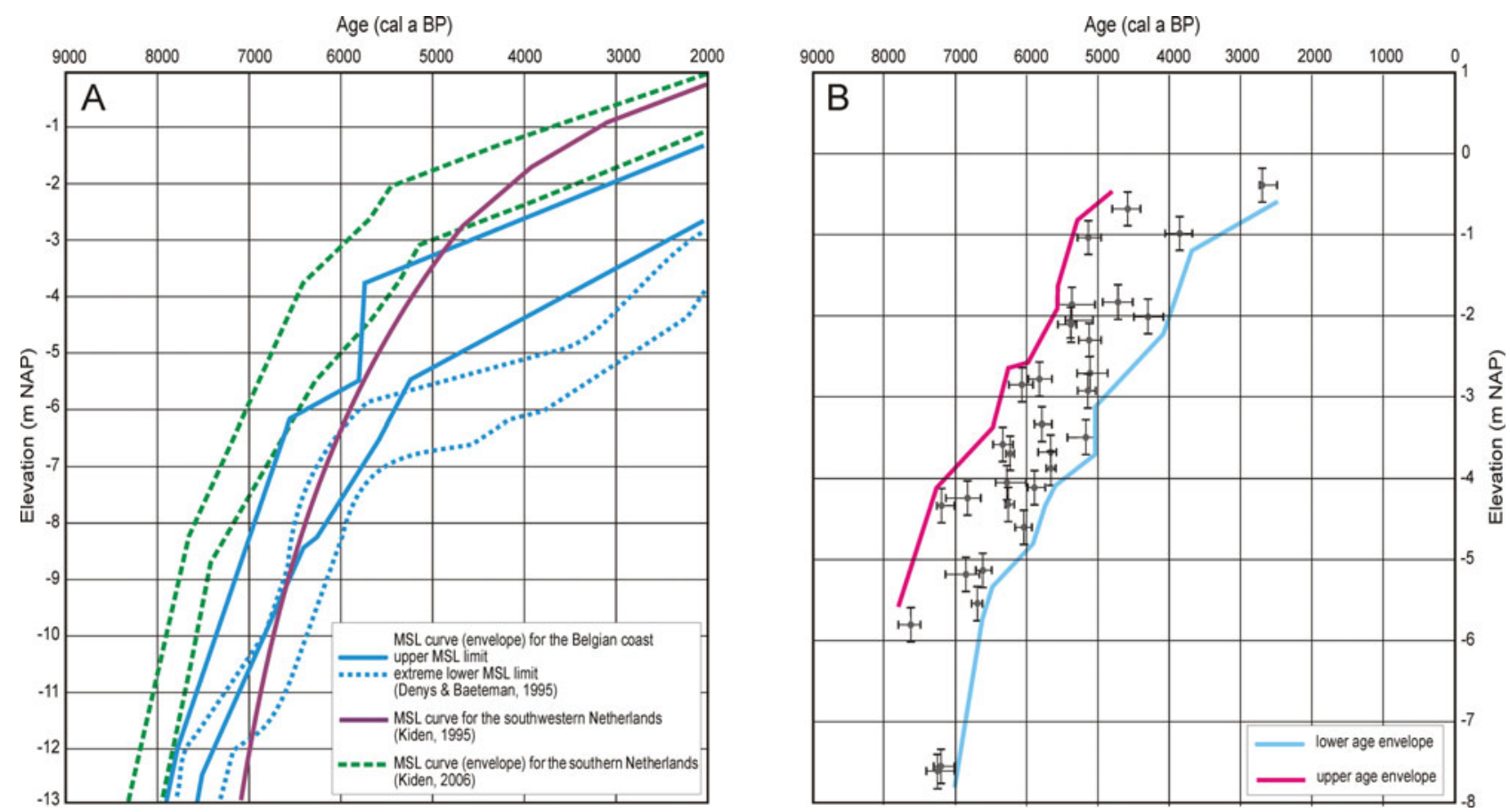

Fig. 6. Left: Holocene relative sea-level curves for the Belgian coast and the S(W) Netherlands (Denys \& Baeteman, 1995; Kiden, 1995, 2006). Right: Age-depth model of the base of the peat sequence in the Waasland Scheldt polders (adapted from Verhegge et al., 2014). Grey crosses indicate the age and elevation of the peat base samples collected in the Scheldt polders. The red and blue line indicate the upper and lower age envelope for this cluster of ages.

getting thinner towards the southwest, away from the river, where the Pleistocene coversand almost surfaces. The middle Holocene marine clay deposits are only present in the deeper parts. It should be noted here that not all the (channel) features of the cross-sections are equally visible on the map in Figure 5 since the latter is based on a generally coarser grid and involved a certain amount of smoothing which may have filtered out small topographical details.

\section{Palaeogeographical and palaeoenvironmental evolution and human occupation and impact}

\section{Late Glacial to early Holocene $(14,500-8200$ cal BP)}

Rising temperatures during the Late Glacial (c. 14.5-11.5 ka cal BP) caused an increase in vegetation cover, which resulted in better soil fixation and less erosion, except for the colder Dryas stadials (Verbruggen etal., 1996). Fossil pollen from organic palaeosols, intercalating the aeolian deposits within the coversand region (Crombe et al., 2012), indicate that during most of this period shallow marshy conditions locally occurred in the study area, with Cyperaceaea (sedges) and Poaceae (grasses) as predominant herbaceous components. Surprisingly, traditional Late-Glacial arboreal taxa, such as Salix sp. (willow), Betula sp. (birch) and Pinus sp. (pine), were less prominently observed, probably pointing towards more site-specific controls (e.g. hydrology, basin morphometry, catchment size) on plant habitats and adaptation. However, during the warmer Allerød interstadial (c. 13.8-12.6 ka cal BP) Pinus sp. is more present (Deforce et al., 2005), especially from c. 13,400-13,300 ka cal BP onwards (late Allerød).

Figure 8A shows the landscape at the start of the Holocene (c. $11.5 \mathrm{ka}$ cal BP). Late Glacial/early Holocene channel erosion by the proto-Scheldt river and small effluents can be distinctly detected. Most likely, only the channels deeper than $-4 \mathrm{~m}$ NAP were active river or stream channels, while the area between -2 and $-4 \mathrm{~m}$ NAP might have been flooded occasionally during heavy rainfall. In the latter area a thin $(\leq 20 \mathrm{~cm})$ layer of muddy sediment, thinning out further away from the river Scheldt, can be distinguished in some of the sediment cores and geotechnical measurements, probably representing flood sediments. It is not unlikely that this thin mud layer may be present in more places but was not detected due to the resolution of the geotechnical data (often $>10-20 \mathrm{~cm}$ ) or to the fact that peat growth on top obscured its presence. Moreover, these flood deposits may also have been (partly) eroded or reworked by the Mid-Holocene marine incursion. This could explain why they do not appear on the cross-sections in Figure 7. The palaeoriver channels fit well with the early Holocene palaeo-Scheldt reconstruction of Kiden $(1995,2006)$ as well as the early Holocene palaeoenvironmental reconstruction of the Netherlands (Vos \& van Heeringen, 1997; Vos et al., 2002) (Fig. 11A, further below). 

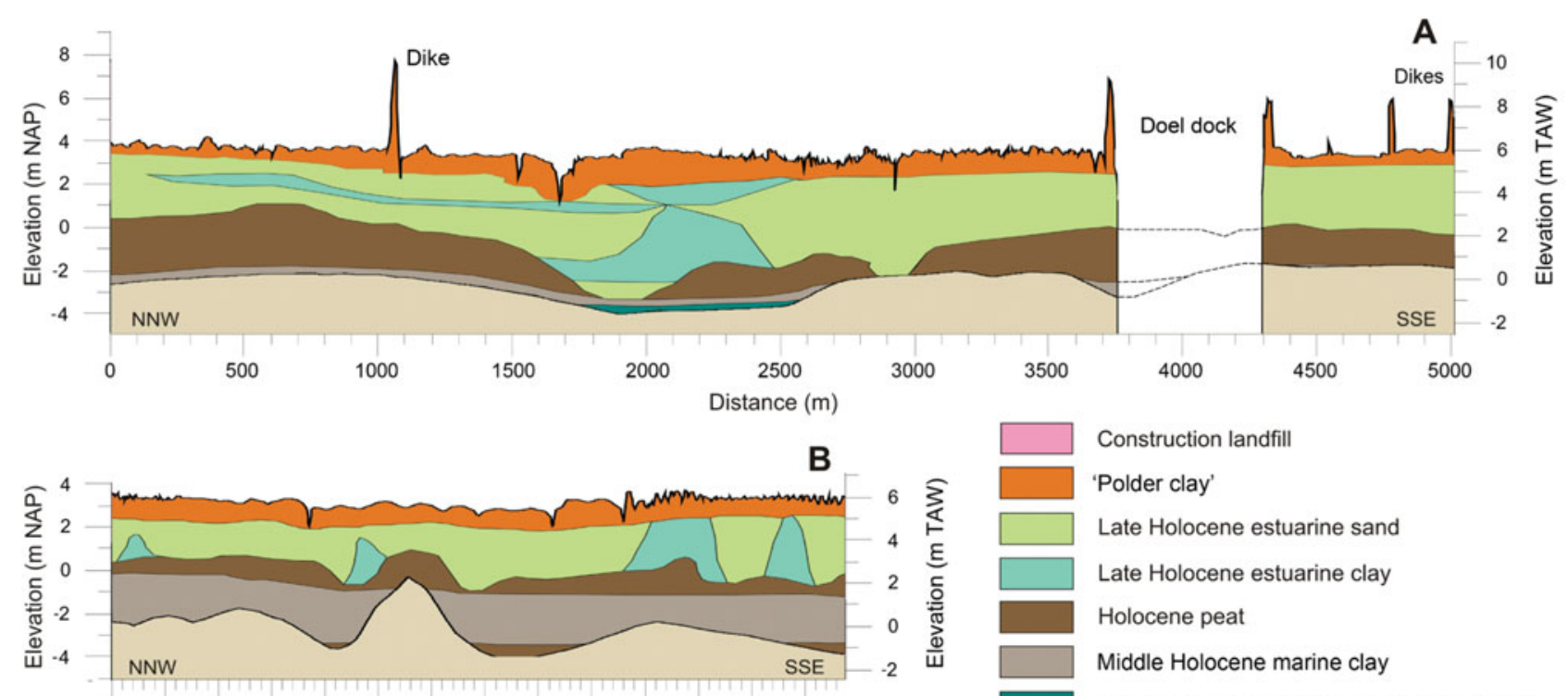

$\begin{array}{llllllllllllll}0 & 100 & 200 & 300 & 400 & 500 & 600 & 700 & 800 & 900 & 1000 & 1100 & 1200 & 1300\end{array}$ Distance (m)

Early Holocene meandering river sediments Pre-Holocene sands

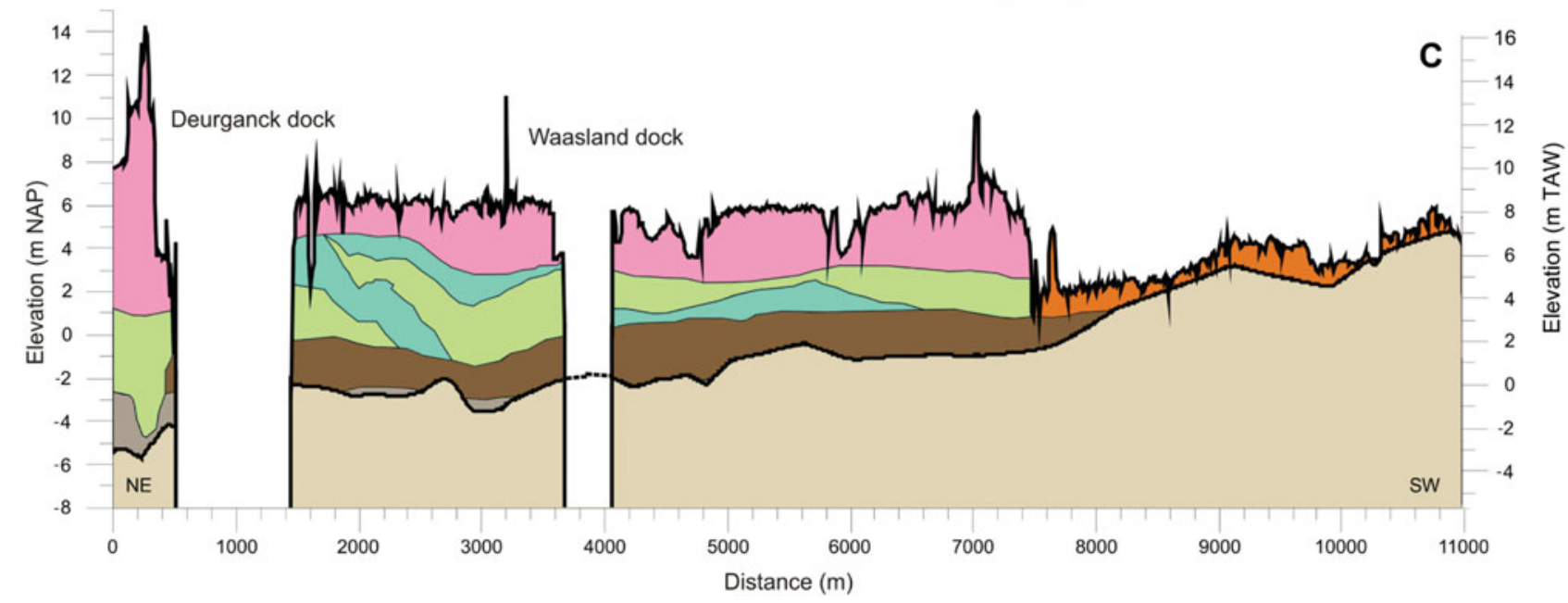

Fig. 7. Schematic cross sections through Nieuw-Arenberg polder (A), Doelpolder Noord (B) and Antwerp harbour (C) showing the sequence of Holocene deposits overlying the coversand. A thin layer of Late Glacial / early Holocene meandering river deposits is present in some of the deeper top Pleistocene topography. The erosive power of the tidal channels and the variability of the late Holocene estuarine deposits is clearly visible. At Doelpolder Noord a thick layer of estuarine clay covers the basal peat bed. For location of the sections see Figure 5.

In terms of human occupation a potential local channel running west to east (indicated by the red line in Fig. 5), following the southern edge of the Maldegem-Stekene coversand ridge, seemingly had a strong attraction. This fossil river channel has been studied and sampled in a trench during archaeological excavations at Verrebroek 'Aven Akkers' (Sergant et al., 2007). Over several kilometres along both banks, but mainly along the steep northern bank, numerous sites from the Early $(10,750-$ 9350 cal BP) and Middle Mesolithic (9400-8350 cal BP) have been detected during surveys and salvage excavations (Perdaen et al., 2004; Crombé, 2005; Crombé et al., 2011). Similar occupation patterns are known along other rivers from the Scheldt basin such as the Lower Scheldt (Meylemans et al., 2013) and the Kale/Durme (Crombé et al., 2011, 2013), thus underlining the importance of rivers as providers of drinking water and for transport during the early Holocene.

\section{First part of the middle Holocene (8200-7000 cal BP)}

Rising temperatures during the early to middle Holocene resulted in the development of a denser forest vegetation, reducing soil erosion and runoff to a minimum (Verbruggen et al., 1996). Consequently, the river discharge consistently decreased, causing gradual desiccation of the Late-Glacial floodplains. Only in the deepest channels was some shallow water 

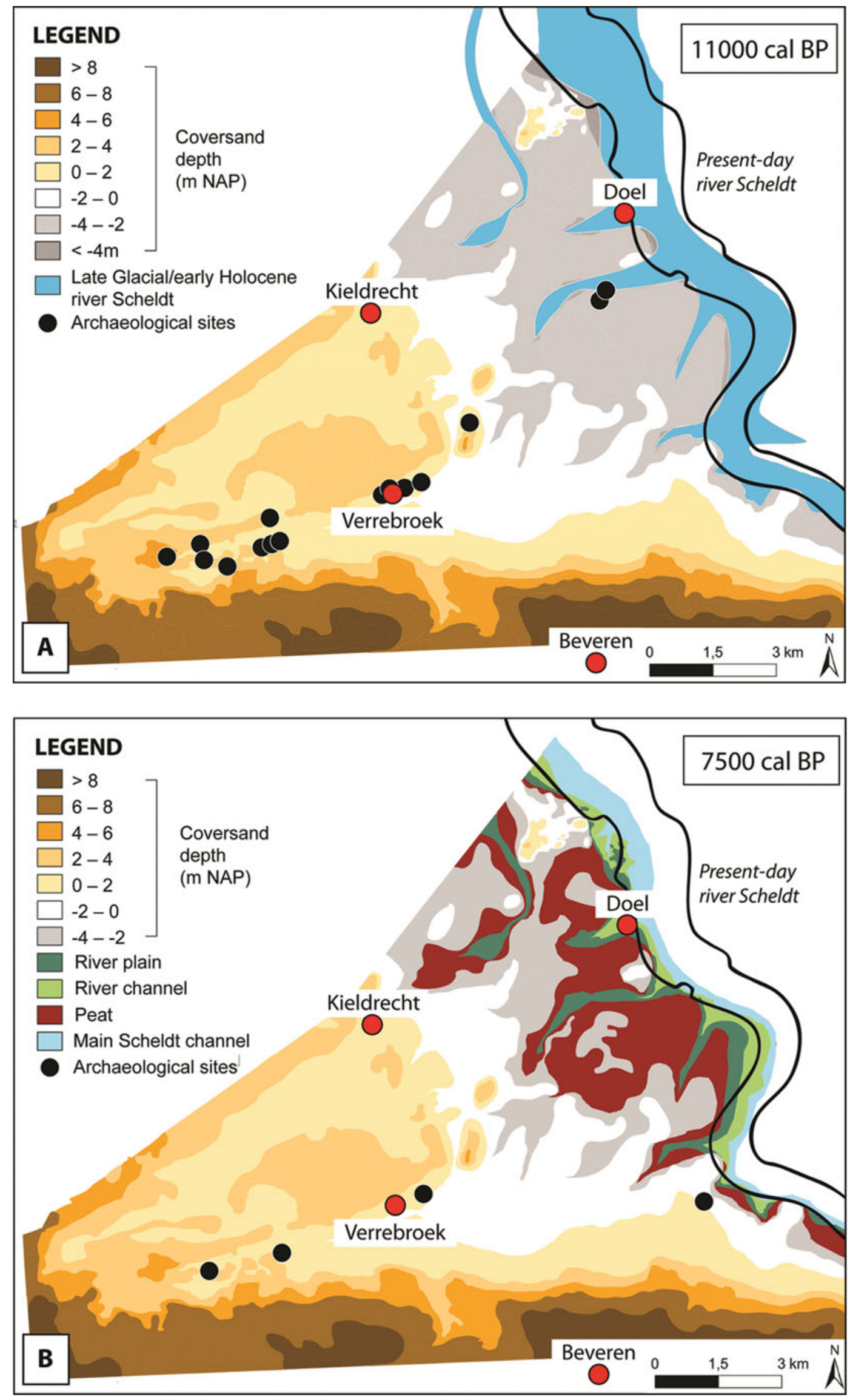

Fig. 8(A, B). Palaeogeographical maps of the Waasland Scheldt polders for different periods. (A) $11000 \mathrm{cal} \mathrm{BP;} \mathrm{(B)} 7500 \mathrm{cal}$ BP. 

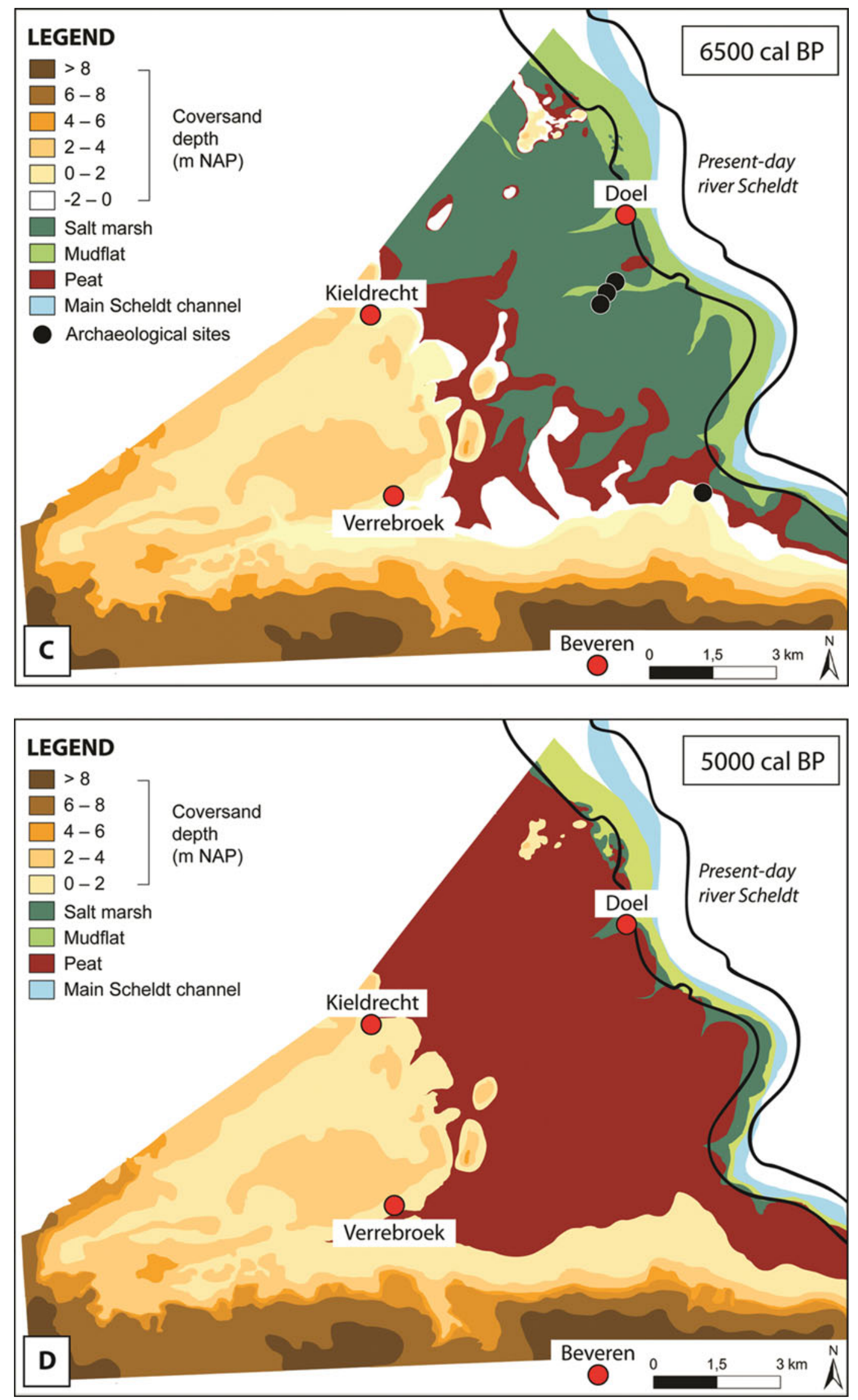

Fig. 8(C, D). Palaeogeographical maps of the Waasland Scheldt polders for different periods (continued): (c) 6500 cal BP; (D) 5000 cal BP. 

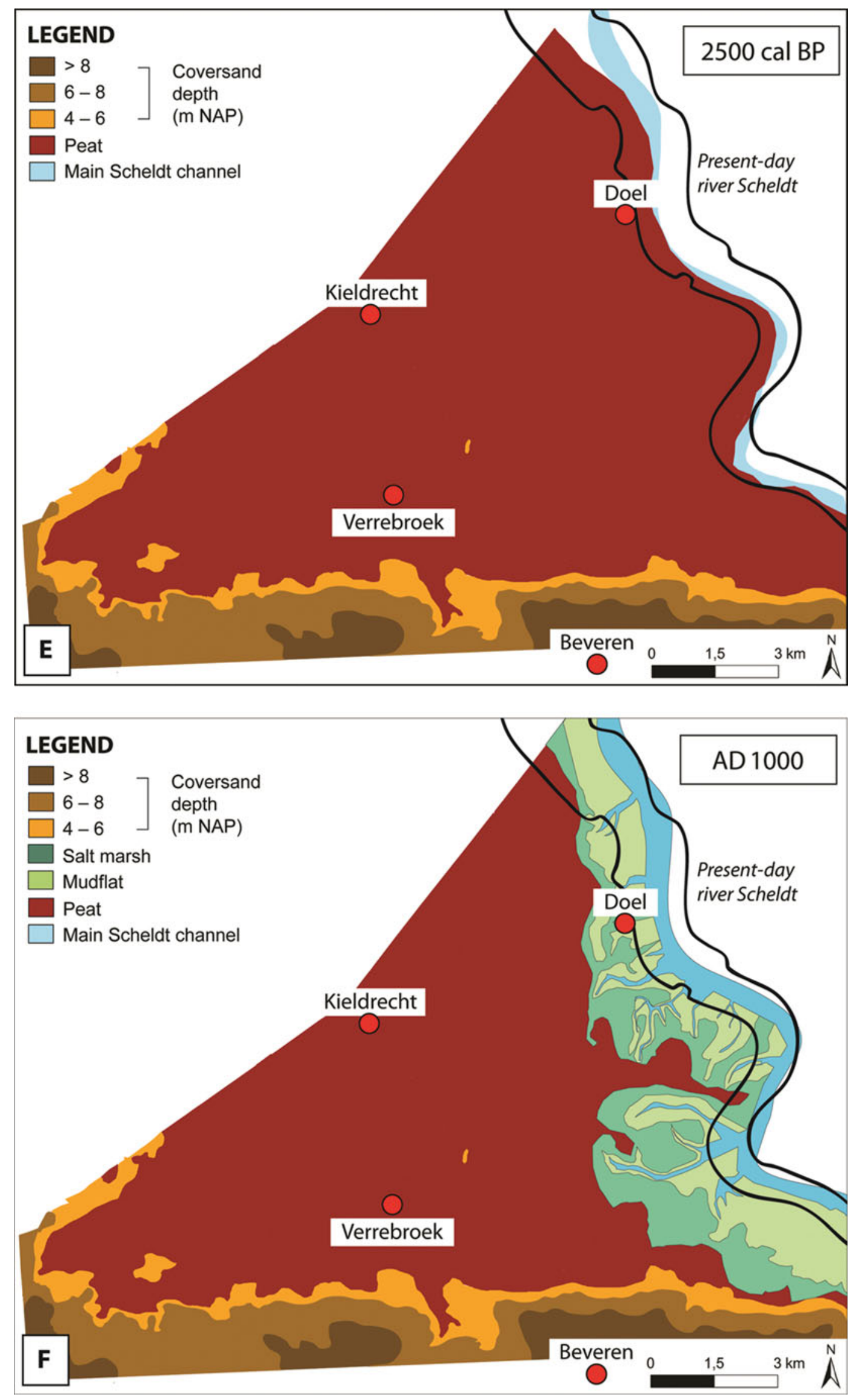

Fig. 8(E, F). Palaeogeographical maps of the Waasland Scheldt polders for different periods (continued): (E) 2500 cal BP; (F) AD 1000. The map shown in $(F)$ is highly tentative. 
still present. In these areas, as part of the hydrosere process, peat also started to accumulate (Kiden, 1991; Kiden \& Verbruggen, 2001; Bos et al., 2005; Bogemans et al., 2012). During this period, the palaeo-Scheldt river flowed northward (Kiden, 2006), while sea level was still rising rapidly, by c. $0.7 \mathrm{~cm} \mathrm{a}^{-1}$ (Denys \& Baeteman, 1995).

The early to middle Holocene landscape of the Waasland Scheldt polders is illustrated in Figure 8B. The Scheldt river south of the Dutch-Belgian border was still a fresh-water environment (in contrast to the SW Netherlands where it had already turned brackish by $8000 \mathrm{cal}$ BP), but on the low-lying banks along the channels peat growth started to develop. Most likely the peat was confined to regions roughly below $-4 \mathrm{~m}$ NAP, around the low-lying river and stream banks. Again a strikingly good correlation can be observed with the corresponding palaeogeographical map of the southern Netherlands by Vos et al. (2002) and Vos \& van Heeringen (1997) (Fig. 11B, further below).

Palaeoecological data from Doel-Deurganck dock indicate that in the lowest depressions/valleys permanent wet conditions occurred, favouring the development of wooded fen, dominated by Alnus (alder) and Fraxinus (ash), whereas in the transition zone (from dry to wet) Corylus avellana (common hazel) occurs (see also Fig. 4, Zone I). On the higher - drier - elevations, i.e. the sand dunes, a predominant dry woodland was present, with Quercus sp. (oak), Tilia sp. (lime) and Corylus avellana (common hazel) as main arboreal components (Gelorini, unpubl. data). The pollen percentage and LOI diagram in Figure 4 indicate an abrupt temporary increase of Tilia around $3.8 \mathrm{~m}$ NAP (Zone II), concurrent with a notable rise in the presence of the parasitic fungi Kretzschmaria deusta (T. HdV-44) and Diporotheca rhizophila (T. HdV-143). This sudden change indicates the temporal development of a local dry Tilia forest phase, in which both parasitic fungi infected most of the potential host populations living in the area, and may be the main agents stimulating the Tilia dominance in the local forest. Hydrological stress, besides some possible damage by domestic animals, is probably the main factor accelerating the disease spread. This is also suggested by a succeeding phase, which is typified by a succession of Alnus, indicating local wetter conditions (i.e. development of alder carr).

Judging by the distribution of Late Mesolithic sites (c. 83507000 cal BP), human occupation and land use changed drastically compared to the early Holocene. The number of sites decreases considerably (see Fig. 8B), indicating a reduced exploitation of the interior and/or a decrease of the group mobility (Crombé et al., 2011). Possible causes may have been the increased density of the forest dominated by deciduous tree species and the decreasing availability of drinking water, driving the last hunter-gatherers to the somewhat higher and therefore drier banks of the Scheldt river where they settled on small levees (Crombé et al., 2015).

\section{Second part of the middle Holocene (7000-5000 cal BP)}

During the middle Holocene, relative sea-level rise dropped to c. $0.4-0.25 \mathrm{~cm} \mathrm{a}^{-1}$ (compared to $0.7 \mathrm{~cm} \mathrm{a}^{-1}$ prior to $7500 \mathrm{cal} \mathrm{BP}$ ) (Denys \& Baeteman, 1995; Kiden, 1995). The sedimentation rates were, however, relatively low due to the limited sediment supply and the low transport capacity of the rivers. The tidal activity in the study area was still limited, in comparison to the SW Netherlands where a shallow, lagoonal environment had already developed in the vicinity of the Scheldt estuary; around 6500 cal BP the sea reached its most inland position in Zeeland (Vos and van Heeringen, 1997). By 6500-6000 cal BP the river Scheldt had turned brackish south of the Dutch/Belgian border (Vos \& van Heeringen, 1997), and the part of the Waasland Scheldt polders closest to the Scheldt river changed into an extended tidal landscape with mudflats (including tidal channels) and salt marshes (Fig. 8C).

The limit of the marine flooding in the study area was determined using the occurrence of the Holocene (peri-)marine deposits and the peat growth model by Verhegge et al. (2014). Most of the early Holocene fens drowned and were covered with an organic-rich alluvial clay (Zone II in Fig. 4). According to Deforce et al. (2014b) the lack of Phragmites (Poaceae) and Salix may seem to suggest a fresh-water environment. However, given the presence of dinoflagellates Spiniferites and $0 p$ erculodinium israelianum and an increase of Chenopodiaceae, it seems more likely that the clayey sediments are deposited under brackish circumstances. This corroborates earlier studies by Minnaert \& Verbruggen (1986) and Verbruggen \& Denys (1995). Surprisingly, during this phase also indications of crop cultivation (cf. cereal type) are found; however, its origin (autochthonous/allochthonous) is unknown. Some fens, however, continued to develop, mostly confined to the transition zone between the tidal areas and the higher Pleistocene coversands. This peat most likely accumulated in areas below $-2.5 \mathrm{~m}$ NAP.

During this middle Holocene flooding phase the transition from a hunter-gatherer to an agro-pastoral economy took place. Prehistoric groups belonging to the Swifterbant Culture (c. 6500-5950 cal BP) and Michelsberg Culture (c. 5950-5600/5500 cal BP) were again attracted to the interior, settling on the same coversand ridges as their early Holocene predecessors (Crombé \& Sergant, 2008). By that time these dunes were already largely reduced in occupation surface due to peat growth and flooding, explaining also why these small sandy outcrops are not visible in the landscape model. In most cases just the small top part of the river dunes or coversand ridges was still available for settling. This was covered by alluvial hardwood forest dominated by Quercus sp., Tilia sp., Ulmus sp. (elm) and Fraxinus excelsior (common ash) with a rich shrub layer, including Cornus sanguinea (common dogwood) and Viburnum opulus (guelder rose) (Bastiaens et al., 2005; Deforce et al., 2013, 2014a; Crombé et al., 2015). These alluvial forests are characterised by the 
highest species richness, productivity and structural and successional complexity within the temperate forest ecosystems (for references, see Deforce et al., 2013, 2014b).

Archaeobotanical analysis (Deforce etal. 2013, 2014a) demonstrated that the Swifterbant groups who settled on these dunes mainly consumed seeds, nuts and fruits from the trees and shrubs growing on the dunes, e.g. Quercus sp. (acorns), Cornus sanguinea (dogwood berries), Corylus avellana (hazelnut), Malus sylvestris (crab apples), Prunus spinosa (sloe plums) and Viburnum opulus (guelder rose berries). Thousands of calcined bone remains collected during excavations demonstrate that hunting and fishing were also part of the subsistence. The dominance of cyprinids among the fish remains points to the presence of large creeks with stagnant to slow-running fresh water (Van Neer et al., 2013). Also the availability of Viscum album (mistletoe) and Hedera helix (ivy) may have contributed to the attractiveness of these sites. The large numbers of charcoal from Viscum album (mistletoe) and charred seeds from Hedera helix (ivy), collected during excavations, have been interpreted as an indication for animal husbandry from the mid-7th millennium cal BP onwards (Deforce et al., 2013). Both plants are evergreens, and were commonly used as winter leaf fodder during (pre)historic times, as documented by plenty of archaeobotanical and historical data.

\section{Transition middle to late Holocene ( 5000-2500 cal BP)}

During the middle to late Holocene the relative sea-level rise decelerated from c. $0.4-$ c. $0.25 \mathrm{~m} \mathrm{a}^{-1}$ to $0.07 \mathrm{~m} \mathrm{a}^{-1}$ (Denys \& Baeteman, 1995), leading to a more balanced net sedimentation. As the tidal landscape started to fill up, peatland started to expand seaward in a relatively short period of time. According to Vos and van Heeringen (1997), the tidal area of Zeeland (southern Netherlands) was completely covered by peat in a period of c. 500 years. In the Waasland Scheldt polders at the southern edge of the Zeeland region a substantial peatland area already existed around $5000 \mathrm{cal}$ BP (Fig. 8D). This is in good agreement with the landscape reconstruction in the southern Netherlands (11C, further below).

In our study area this renewed peat formation took place under more mesotrophic conditions (e.g. at Kallo-Vrasene Dock, Doel-Deurganck dock). Here, the alder carr vegetation was directly succeeded by more open sedge fens, characterised by Cyperaceae, Poaceae and filicales, and poor fen stages with Betula and Myrica gale (bog myrtle) (e.g. Munaut, 1967; Janssens \& Ferguson, 1985; Minnaert \& Verbruggen, 1986; Gelorini et al., 2006; Deforce, 2011). Over the next 1000-1500 years the peatland slowly expanded further westward towards higher grounds, with the exception of a few small 'islands' of coversand, which were nevertheless enclosed by peat. At the earliest, around 4000 cal BP (at Doel; see Deforce, 2011) the sedge fen was gradually replaced by oligotrophic peat bogs, mainly consist- ing of Ericaceae (heath), Sphagnum (peat moss) and Myrica gale (e.g. Gelorini et al., 2006; Deforce, 2011). However, at some sampling sites (as from, e.g., Doel-Deurganck dock and Kallo-Vrasene dock) this bog stage was preceded by a shortlived establishment of Pinus (pine) forests, probably resulting from site-specific edaphic differences (i.e. local dryer conditions) (Janssens \& Ferguson, 1985; Gelorini et al., 2006).

For humans, the Waasland Scheldt polders seemed much less attractive during this period, probably due to the extent of more open peatland, reducing the capability of settlement development (i.e. most dunes were gradually covered by peat) and decreasing the availability of food resources. Late Neolithic and Bronze age sites are currently only known from the dry hinterland to the west and south of the Waasland polder area (Thoen, 1989; De Reu et al., 2011).

\section{Late Holocene (2500-1500 cal BP)}

Around 2500 cal BP the coastline barriers were breached at several locations in the SW Netherlands (Vos \& van Heeringen, 1997; Vos, 2002). As a consequence, in the surroundings of these coastal barriers peat growth ceased. The Waasland Scheldt polders, however, are located much further inland, well protected from the invading sea, favouring the continuous accumulation of peat. Here, at different sampling locations, radiocarbon measurements on the topmost part of the peat seem to demonstrate that peat formation probably continued - at least at some sites - until at least 1220 cal BP (c. AD 730) (Kiden, 1989; Van Strydonck, 2005; Gelorini et al., 2006; Deforce, 2011; Verhegge et al., 2014).

The exact extent of the peat has been a subject of debate in Belgium between geoscientists (e.g. Verhoeve \& Verbruggen, 2006) and historians (e.g. Soens \& Thoen, 2009). Geoscientists expect traces of peat growth in the soil and/or subsoil. Therefore, if no traces of peat are found, past peat growth is considered doubtful (this viewpoint was, however, already questioned by Vos \& van Heeringen, 1997). Historians, on the other hand, use information from historical records and maps and accept more circumstantial evidence like place names or written records of peat extraction as a corroboration of peat presence (Soens \& Thoen, 2009). Recently, Jongepier et al. (2011) showed that combining geographical and historical data can help to bridge the gap between geoscientists and historians.

In the eastern part of the Waasland Scheldt polders, peat is clearly present in sediment samples and/or indicated by the geotechnical data (CPT logs) (white hashed area in Fig. 9). The top of the peat layer surprisingly has a maximum elevation of c. $1 \mathrm{~m} \mathrm{NAP}$ (or $3.3 \mathrm{~m} \mathrm{TAW}$ ) (see Fig. 7), which is exceptionally high for the region. Formerly, the highest point up to which peat growth had been recorded in the Waasland Scheldt polders ranged roughly between -1.3 and $-0.8 \mathrm{~m} \mathrm{NAP} \mathrm{(or} 1$ and $1.5 \mathrm{~m}$ TAW) (Crombé et al., 2005; Meersschaert et al., 2006). According to Verhoeve \& Verbruggen (2006) this is the threshold level 


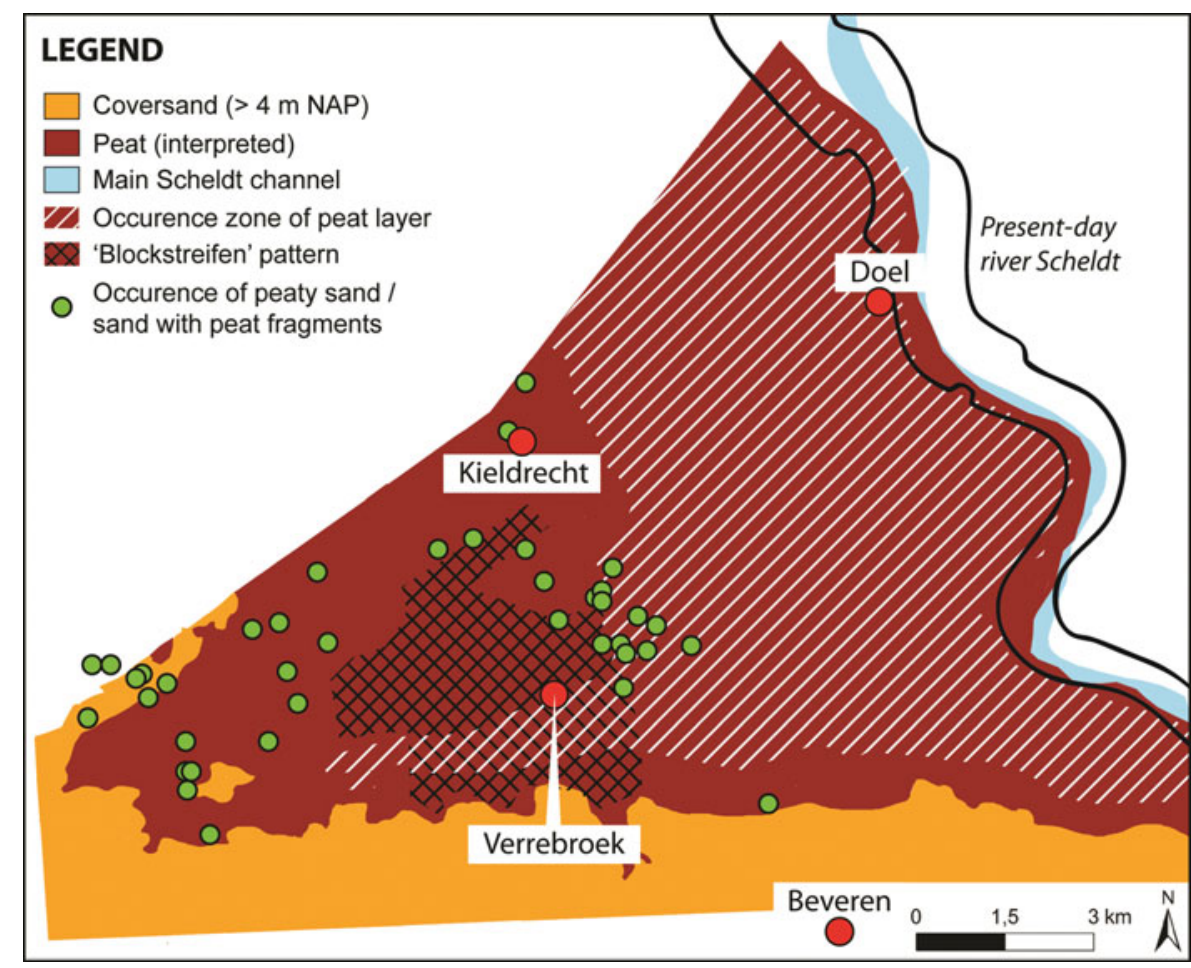

Fig. 9. Palaeogeographical map of the peat expansion in the Waasland Scheldt polders around $2500 \mathrm{cal} B P$. This situation likely lasted till c. $1350 \mathrm{cal} B P$. The white hashed area indicates where peat was detected in the cores and/or geotechnical data. Green dots mark sediment cores with a presence of peaty sand or sand with peat fragments, but where no defined peat layer was found. The black hashed area indicates where traces of medieval drainage features ('Blockstreifen' pattern; see also Fig. 10) are still visible. for peat growth, as locations above $1.5 \mathrm{~m}$ TAW (-0.8 $\mathrm{m} \mathrm{NAP}$ ) are generally considered to be too dry. In the best case, an impermeable layer in the shallow subsurface needs to be present to retain rainwater in the soil. However, Ovaa et al. (1957) state that in lower depressions between sand ridges the substrate is impermeable enough to allow peat growth and that in the past wetter conditions must have existed in these depressions as drainage was considerably worse. The depressions southeast of Kieldrecht seems to have fulfilled these requirements, where traces of peat have been recorded in a number of sediment cores (green dots in Fig. $8 \mathrm{E}$ ). Since the data points for this part of the Waasland Scheldt polders are unevenly spaced and the sediment descriptions are based on subsurface samples at a $50 \mathrm{~cm}$ interval, it seems likely that peat layers may not have been detected.

There is also a lot of historical evidence concerning peat exploitation. Already in the 12th and 13th centuries, peat exploitation in the Waasland Scheldt polders was very significant (Jongepier et al., 2011). According to Augustyn (1999), around $\mathrm{AD} 1300$ the counts of Flanders realised an annual production of about 8000 'last' of peat - one last equalling 10,000 blocks of peat - on their estates in this region. Unfortunately, the historic documents seldom mention where exactly the peat was dug. However, it is known that two major reclamation centres were founded in Kieldrecht and Verrebroek (Augustyn, 1985). The peat reclamations presented a so-called Blockstreifen pattern with long, narrow parcels of land separated by ditches, often starting at a road or waterway (Gottschalk, 1984). This pattern can still be identified in the region on the DEM or on aerial pictures (Fig. 10); its extent is shown in Figure 9 (black hashed area). Some geoscientists consider the presence of this Blockstreifen pattern insufficient to prove the existence of peat (e.g. De Muynck, 1976). However, the fact that the pattern is visible in the medieval morphology (i.e. in areas where the late medieval surface is not covered by post-medieval tidal deposits) supports the historical records. The thin peat layer (roughly $10 \mathrm{~cm}$ ) that was mostly left behind during the exploitation may easily be missed due to the low sampling resolution in the cores $(50 \mathrm{~cm}$ or more), or it may have disappeared altogether due to drainage and oxidation, or due to erosion during later inundations. It is likely that such a Blockstreifen pattern also existed further north, in the area around Kieldrecht (Augustyn, 1999), but the large floods in the 16th-17th century have wiped out all evidence.

Based on the assumptions stated above, it therefore seems likely that the Waasland Scheldt polders landscape would have been completely covered with peat around 2500 cal BP (Fig. 8E), and this situation likely persisted for c. 1000 years (till c. 1500 cal BP). The map of 2500 cal BP also agrees well with the palaeoenvironmental reconstruction of the Netherlands for this period (Vos \& van Heeringen, 1997; Vos et al., 2002) (Fig. 11D, further below). This complete peat coverage might explain the - so far - total absence of archaeological sites belonging to the Iron Age and Roman Period in the Waasland Scheldt polders. However, studies from the Belgian coastal plain (Baeteman, 2007; Demey et al., 2013, Baeteman \& Pieters, 2015) and the SW Netherlands (De Clercq, 2009; De Clercq \& Van Dierendonck, 2009) indicate human activity in these areas that were 


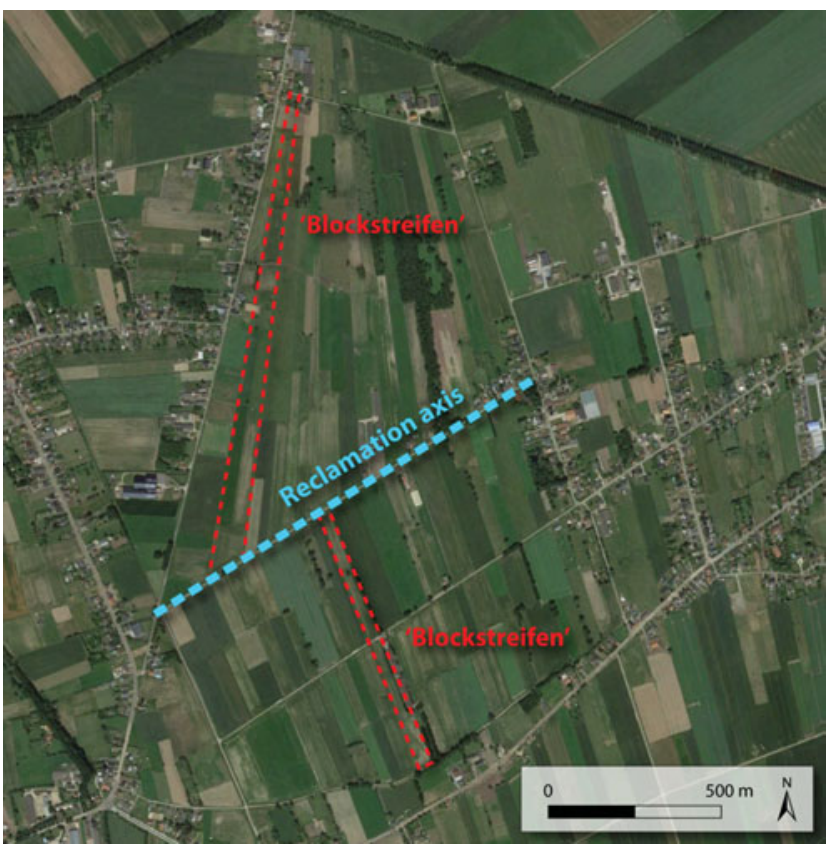

Fig. 10. Google Earth (C) image of the area around Verrebroek (for location see Fig. 1) showing the presence of a medieval 'Blockstreifen' pattern (red dotted lines) in the landscape where the late medieval surface is not covered by tidal deposits. Drainage of the peat lands was done by digging many ditches, perpendicular to reclamation axes (mostly a road, indicated in light blue).

characterised by large peat bogs at that time. It is not unlikely that the large-scale extraction (and erosion) of the peat may have (partly) destroyed the archaeological evidence from Iron Age and Roman sites in the study area.

\section{Middle Ages (1500-500 cal BP) (AD 500-1450)}

As stated earlier, the man-made transformation of the landscape through dike building, draining and peat extraction started in the 11th and 12th centuries. Unfortunately, it is still uncertain what the landscape looked like prior to these man-induced landscape changes. 0nce drained, peat soils often became subject to rapid erosion and shrinkage, as documented for many peatland regions in the western and northern Netherlands (e.g. Borger, 1992; Vos, 2015). The extraction of the peat further accelerated this process. As result of this human interference and the disappearance of the top layer of peat, a depositional hiatus of several centuries is visible in the soil archive from the documented end of the peat growth in the 7th-8th centuries $A D$ until renewed flooding and deposition of estuarine clay deposits, locally attested in the 10th-11th centuries and more widespread in the 13th century AD (Deforce, 2011). Because of both peat erosion/extraction and overlying estuarine deposits, the reconstruction of the early medieval landscape before the start of large-scale drainage and embankment remains tentative.
It seems likely, however, that the landscape during the Early Middle Ages looked similar to the landscape a thousand years earlier, except for some tidal flats and salt marshes close to the river Scheldt. Augustyn's (1977) statement that in the Early Middle Ages the Waasland Scheldt polders consisted of a peat bog with some small sand ridges and pools in between may well be a correct description. On the present DEM (see Fig. 2) and on the soil maps some of these old creeks can still be distinguished, but it is almost impossible to determine the age of these features. Using the soil map (AGIV, 2000) and geological knowledge of the area, a tentative palaeogeographical reconstruction was made for c. AD 1000 (Fig. 8F). Both archaeological and historical traces of human occupation before AD 1000 are missing. This does not imply that the area was completely uninhabited. A low-intensive land use directed at the exploitation of the wetland resources (pasturing, fishing, fowling, etc.) is possible parallel to what happened in other parts of the coastal wetlands in this period (see Soens et al., 2014).

Starting in the 11th or 12th century, small-scale dams were built, which either served as elevated roads in the wetland area or as drainage improvements. Archaeological excavations recently discovered the remains of such a dam south of the village of Kieldrecht (Cryns et al., 2014). In this period, ownership over the unreclaimed 'wastelands' was gradually established by local lords - the lord of Beveren, whose castle Singelberg was situated immediately north of the higher cuesta (Wilssens et al., 2007). For the 13th and 14th centuries, historical sources inform us of the systematic reorganisation of the landscape. In the surroundings of the villages of Kieldrecht and Verrebroek, a pattern of dikes (so-called moerdijken or 'peat dikes'), ditches and roads was set up in order to excavate and transport the extracted peat (Augustyn, 1999).

Closer to the river Scheldt, marshlands were protected from flooding by dikes from the 13th century onwards and turned into 'polders' (e.g. the Harnesse in Kieldrecht, protected by dikes in 1262) (Van Roeyen, 2007). In the 14th and 15th centuries, larger dikes were built in order to keep the Scheldt floods out, but the water of the Scheldt increasingly invaded the lowlying region. Combined with the increasing tidal influence on the river Scheldt, the region had become very vulnerable to floods as the land level in many cases was lowered through the drainage, shrinking and extraction of the peat (Vos and van Heeringen, 1997; Soens, 2013). A highly dynamic period of floods, alternated with renewed land reclamation through embankment set in.

Archaeobotanical analyses (fossil pollen and plant macrofossils) revealed that in the 14th-16th centuries the southern part of the Haendorp polder (for location see Figs 1 and 12) was characterised by a relatively open, agrarian landscape, associated with crop rotation of cereals and leguminous crops such as peas and beans, and limited presence of woodland. In the northern part, where peat remained still (partly) 

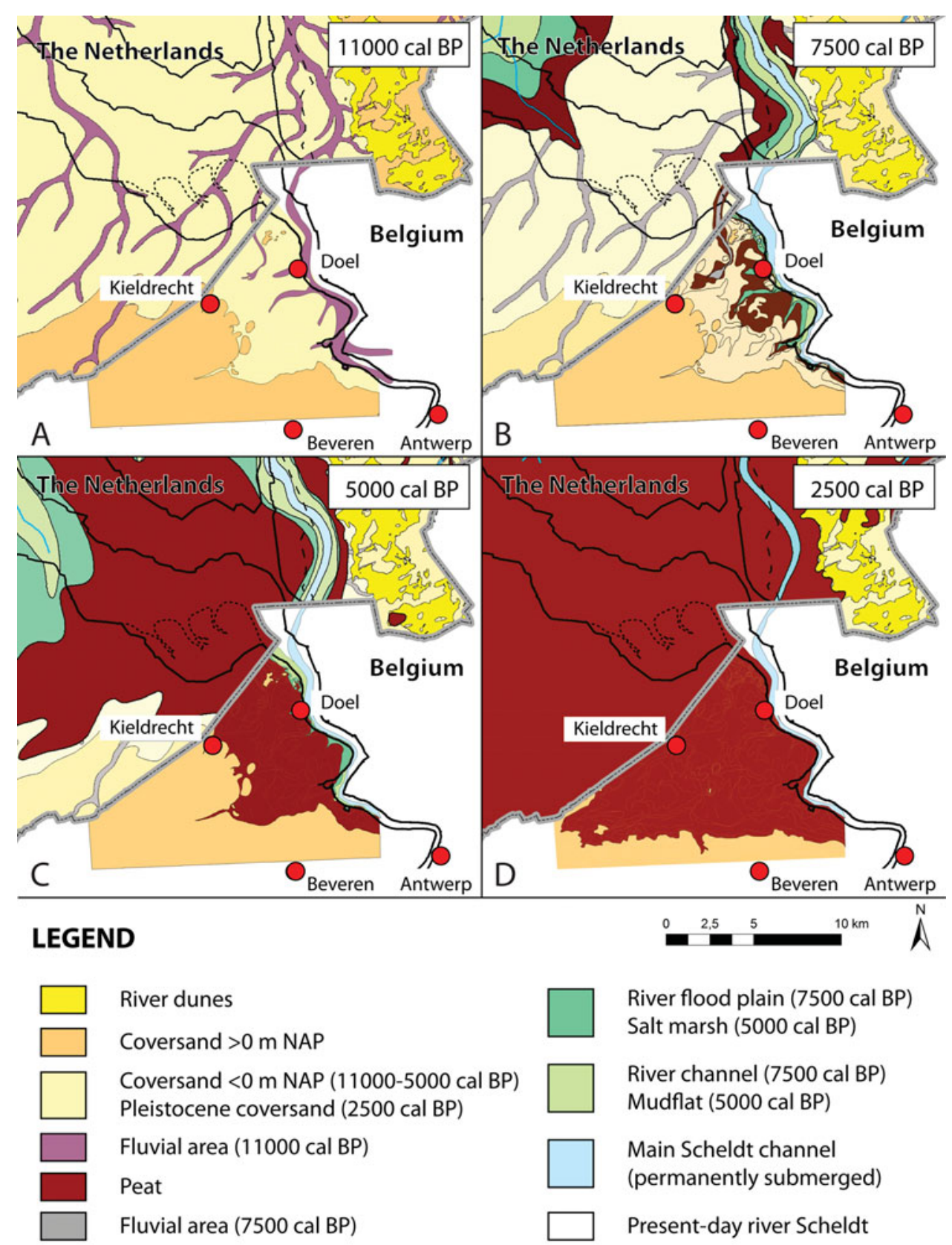

River flood plain (7500 cal BP) Salt marsh (5000 cal BP)

River channel (7500 cal BP) Mudflat (5000 cal BP)

Main Scheldt channel (permanently submerged)

Present-day river Scheldt

Fig. 11. Combined palaeogeographical maps of the Waasland Scheldt polders and the neighbouring southern part of the Netherlands showing a good correlation (partly after Vos, 2002 and Vos \& van Heeringen, 1997). (A) 11,000 cal BP; (B) $7500 \mathrm{cal} \mathrm{BP;}$ (C) $5000 \mathrm{cal} \mathrm{BP;}$ (D) $2500 \mathrm{cal} \mathrm{BP.}$

uncovered, more diverse landscape types occur, consisting of heath and grasslands, shrub and woodland vegetation (Gelorini et al., 2003).

\section{Late Middle Ages till modern times (500-100 cal BP) (AD 1450-1850)}

An important wave of reclamation through embankment of previous flooded land took place from 1431 onwards, when large stretches of marsh were sold by Philip the Good, duke of Burgundy, to private drainage companies (Jongepier et al., 2012). Until 1567, various embankments resulted in the polders of, among others, Hoog-Verrebroek, Kieldrecht and Doel (Van Gerven, 1977). Furthermore, large parts of the peatland earlier excavated were drained and converted into agricultural land. The landscape reconstruction of 1570 (Fig. 12A) shows that by then almost the entire study area was embanked and a large number of (small) villages have been founded. West of Doelpolder, remains of the former peatlands are still found. The salt marsh is limited to the fringes of the river Scheldt outside of the dikes. In contrast to the earlier embankments of the Middle Ages, which were often more curved in shape, dictated by the landscape, these later embankments became increasingly linear. From the 17th century onwards the typical 


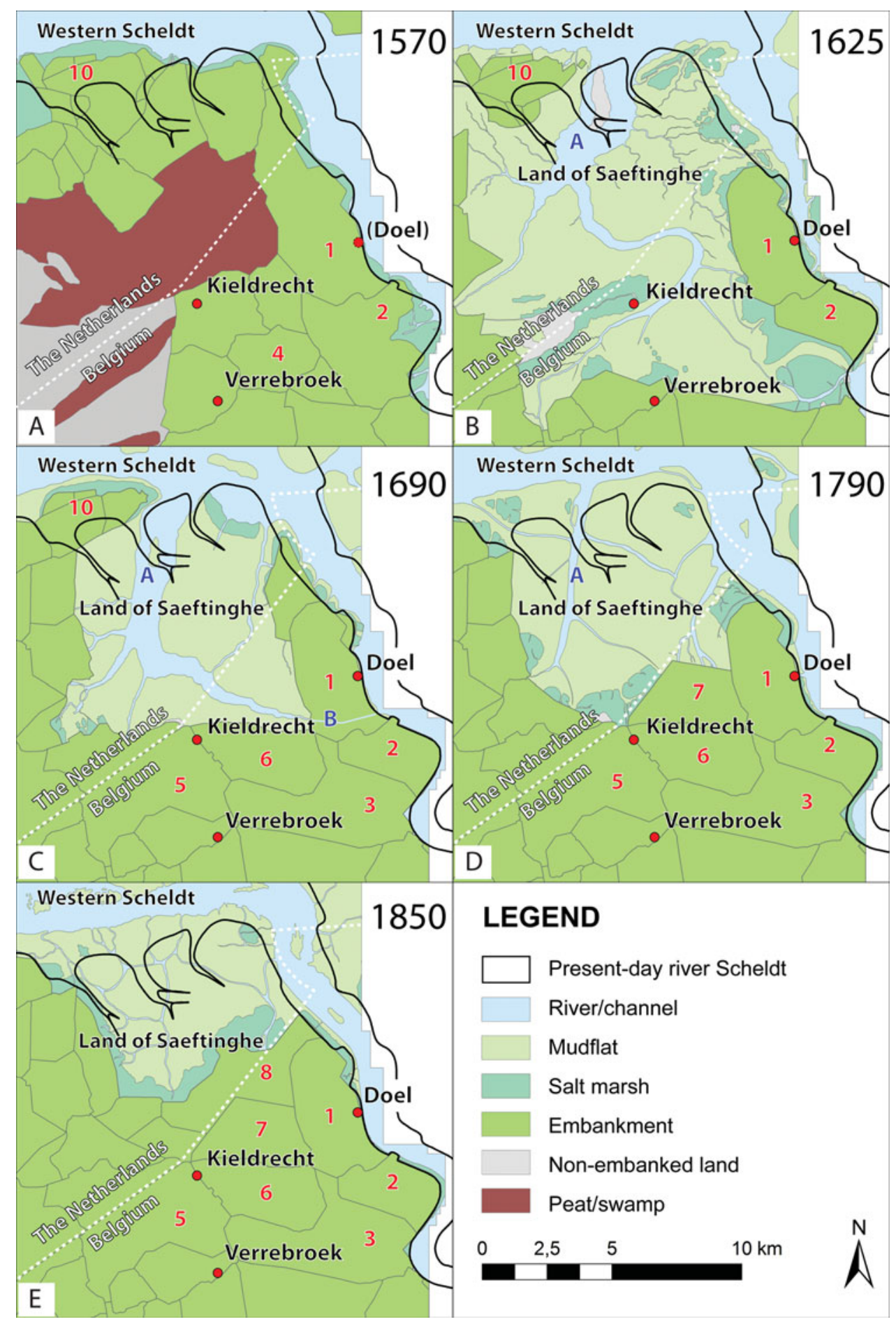

Fig. 12. Post-medieval palaeolandscape maps for different time periods (adapted after Jongepier et al., 2015b). (A) AD 1570; (B) AD 1625; (C) AD 1690; (D) AD 1790; (E) AD 1850. Numbers and letters refer to sites discussed in the text. $1=$ Doelpolder; $2=$ Sint-Annapolder; $3=$ Kallopolder; $4=$ Polder van Haendorp; $5=$ Konings-Kieldrechtpolder; $6=$ Oud-Arenbergpolder; $7=$ Nieuw-Arenbergpolder; $8=$ Prosperpolder; $9=$ Hedwigepolder; $10=$ Polder van Namen; $A=$ Saeftinger gat; $B=$ Deurganck. The white dashed line marks the present-day border between Belgium and the Netherlands.

embankment layout was in regular (orthogonal) grids (Soens et al., 2014).

Military inundations during the Eighty Years' War (15681648) resulted in renewed flooding of large parts of the Waasland Scheldt polders. The impact of the floods was severe due to centuries of peat extraction and drainage, accompanied by compaction, which had significantly lowered the surface of the land (often lower than Mean High Water Level) (Vos, 2015). This meant that large areas could easily be flooded once the dikes were breached. Since no immediate recovery 
plans for the drowned area were made, an extensive tidal flat developed (Land of Saeftinghe), cut by a large tidal channel (so-called Saeftingher Gat). The landscape reconstruction of 1625 (Fig. 12B) shows how this tidal flat extended far into the Waasland Scheldt polders. Only the higher areas such as the village centre of Kieldrecht (on a sandy ridge) and the polders of Namen, Doel and Sint-Anna escaped complete flooding. Most of the villages that existed in 1570 appear to have been drowned now.

In the centuries after the end of the Eighty Years' War (in 1648) the entire area was gradually re-embanked. The first areas to be re-embanked included Doelpolder and Sint-Anna polder (which had largely escaped flooding) in 1614, and the polders south of Verrebroek in 1618. The landscape reconstruction of 1690 (Fig. 12C) shows some continuity with the landscape in 1625 , but the course of the main tidal channel has changed and it now runs due east to the Doelpolder where an internal connection to the Scheldt river was established (the so-called Deurganck; see Fig. 12C), probably in order to facilitate future military inundations. Most of the tidal area consists of low-lying mudflats. Due to the successive embankments, sedimentation seaward of the new sea dikes was reinitiated after each embankment, leaving little time for higher salt marshes to be formed.

In the course of the 18th century, embankment continued with the Nieuw-Arenbergpolder (in 1729-1784). Dikes became higher and stronger, but especially the landscape 'design' changed drastically: while medieval embankments were often consistent with the natural topography, the early modern embankments were characterised by a regular pattern of perpendicular roads and ditches and a rectangular parcelling, neglecting all natural features (De Kraker, 2007). Due to the larger embanked area, the volume of the tidal area decreased, and therefore the flood and ebb discharges going through the tidal channel system were reduced, causing sedimentation in the channels themselves (D'Alpaos et al., 2006; Vandenbruwaene et al., 2012). The landscape reconstruction of 1790 (Fig. 12D) shows that, apart from the new embankments, almost a century of sedimentation has allowed the salt marsh to be heightened in the Land of Saeftinghe. The tidal channel is much reduced in size and the area of lower salt marsh has extended, but also higher salt marsh has developed against the sea-dikes of most of the embankments.

The process of salt marsh formation persisted in the period 1790-1850. By then, almost the entire tidal flat was bordered by a salt marsh, located along the outer dikes bordering the remaining intertidal area, and the tidal channel surface reduced even further in size (Fig. 12E).

\section{Synthesis}

In this paper we have described the landscape development of the Waasland Scheldt polders from the Late Glacial - early
Holocene to the present time, and the effects of this changing landscape on the human settlement. The regional landscape evolution has been visualised in a series of palaeogeographical maps for successive time frames; for each map the various driving mechanisms behind the palaeoenvironmental changes and human occupation are discussed. Two different map series were produced: a series of Holocene palaeogeographical reconstructions (11,000 cal BP - AD 1000; Fig. 8) based on geotechnical, geological and archaeological data, followed by a series of post-medieval landscape reconstructions (AD 15701850; Fig. 12) based on historical maps, land registers and soil data. The basis for the Holocene reconstructions was provided by the top Pleistocene relief map (Fig. 5), which was used to determine the maximum extent of the successive marine, peat and estuarine deposits. A solid time frame was provided by relative sea-level curves and a dated peat growth evolution model (for the Holocene landscapes) and old historical maps (for the post-medieval landscapes). Palaeoecological data such as pollen, charcoal and plant macrofossils provided information on the vegetation and wetland changes, particularly for the middle to late Holocene. The landscape of the Waasland Scheldt polders is highly dynamic, and only through these combined methods was it possible to obtain an accurate reconstruction of the (drowning) landscape and to interpret successive stages of human settlement and land use.

In short the evolution of the Waasland Scheldt polders landscape can be described as follows. At the start of the Holocene (c. 11,500 PB) the landscape was marked by coversand deposits, towards the east locally eroded by channels of the palaeo-Scheldt river. Human occupation was concentrated along the southern edge of an E-W-trending sand ridge, most likely the location of a former fossil river channel. Rising temperatures during the early Holocene resulted in the gradual development of a woodland, and peat started to grow in the deeper channels. Human occupation decreased considerably, the last hunter-gatherers settling on small levees on the banks of the Scheldt river, which was still a fresh-water environment. As sea level rose, a large part of the area changed into an extended tidal landscape with mudflats and salt marshes during the middle Holocene. Human occupation again returned to the coversand ridges, though now often concentrating on the top part due to extending peat growth and flooding. Already around 5000 cal BP a substantial peatland area existed, making human occupation increasingly less attractive. During the late Holocene, peat growth gradually took over the entire area. By 2500 cal BP almost the entire area was covered by peat, which probably explains the absence (so far) of Iron Age and Roman settlements. Peat growth probably continued till roughly 1200 cal BP.

During the Early Middle Ages the landscape was still largely peat-covered, except for some tidal flats and salt marshes close to the river Scheldt. Traces of human occupation are missing, but this does not exclude some local land use (pasturing, 
fishing, etc.). Human intervention in the landscape started in the 11th-12th century with the building of small dams (for roads or drainage). From the 13th century onwards dikes, ditches and roads were set up to excavate and transport the peat. Closer to the river Scheldt, larger dikes were built to protect the increasingly invaded low-lying region. Intensive land reclamation through embankment took place, and large parts of the earlier-excavated peatland were drained and converted to agriculture land. By 1570 almost the entire area was embanked, and a large number of villages had been founded. Peatland only occurred in the west. During the next 50 years military inundations resulted in large-scale flooding of the area - a direct result of the increasing tidal influence and lowering of the land through drainage, shrinking and extraction of the peat. Many villages that existed in 1570 were drowned. In the following centuries the area was gradually re-embanked, and the remaining tidal area pushed back to the northern limits (Land of Saeftinghe). Dikes became larger, and the embankments were increasingly characterised by a regular pattern neglecting all natural features. As the tidal area decreased, the marsh in Saeftinghe was considerably heightened.

In contrast to the landscape evolution during the Holocene which was mainly sea-level driven, the landscape transformation during the last millennium (i.e. since the Early Middle Ages) was largely due to human interventions. The latter included both direct landscape modifications (such as the development of a drainage and flood protection infrastructure, agricultural land use or settlement) and their indirect and mostly unintended consequences (such as the dramatic lowering of soil levels due to peat drainage, as well as the increase of storm-flood levels in the estuary as the accommodation space for excess flood water had shrunk due to progressive embankment (Soens, 2013; Vos, 2015; and for the northern Netherlands, Van Dam, 2001; Knol, 2013)). An important key to understanding the landscape evolution of the Waasland Scheldt polders is peat and its nature, growth, coverage and extraction. On the one hand, peat has the great advantage of covering and preserving former landscapes and the archaeological traces of prehistoric occupation it contains. On the other hand, through its transient nature (due to shrinkage, extraction, erosion, etc.), peat often makes landscape reconstruction difficult (as traces of settlement on top of the peat have often disappeared). By combining multiple methods and disciplines, former interpretations of peat growth in the area, which had been the subject of intense debate in Belgium, could now be corrected. The peat evolution in the Waasland Scheldt polders correlates extremely well with the Holocene landscape maps from the SW Netherlands (Fig. 11) by Vos \& van Heeringen (1997) and Vos et al. (2002), although the Dutch maps show less resolution due to the scale involved. More research is still needed to reconstruct the chronology and topography of medieval peat reclamations and the subsequent disappearance of the peat. Traditional historical-geographical and archaeological methods, which were successfully applied to reconstruct medieval peat colonisation in different parts of the Netherlands (Leenders, 1989; Borger, 1992; De Langen, 1992; Ligtendag, 1995; de Bont, 2014) are problematic in regions where the medieval landscape has been covered by thick layers of postmedieval sediments such as our study area. The present palaeogeographical reconstructions, including a detailed mapping of the Pleistocene surface relief, offer a new and solid base for such enquiry.

\section{Conclusions}

The interdisciplinary reconstruction of the Holocene palaeogeography and occupation history of the Waasland Scheldt polders presented here is quite new in Belgium. For the first time a series of detailed palaeogeographical maps and landscape reconstructions has been made that gives an overview of both the long-term (typically thousand-year period, premedieval) and short-term (typically hundred-year period, postmedieval) evolution of this wetland region since the Late Glacial - early Holocene, including recent historical times. Previous reconstructions typically focused on a more limited time period (e.g. Middle to Late Holocene, or post-medieval), did not combine data from such a wide range of disciplines investigating past landscape evolutions or did not attempt to extrapolate data into a coherent landscape model.

The maps presented in this study are based on an extensive body of existing and new data. In the future this database will be continually updated with new information from many different sources (e.g. geology (boreholes), geomorphology, archaeology, datings, palaeoecology, historical data and maps), not only related to academic research but also in the framework of commercial projects (among others, the planned construction of a large new dock (the so-called Saeftinge dock) affecting large parts of Doelpolder and Nieuw-Arenbergpolder). This new information should allow further refinement of the maps, and, where necessary, their modification. Expanding the present maps to a wider regional scale, as was done in the Netherlands by Peter Vos, may seem a logical step but this will require a significant effort. Nonetheless, regional palaeogeographical maps can be a valuable tool for the prospection of buried archaeological heritage because they show which palaeolandscapes (for a specific period) favour human settlement and/or specific human activities. In turn this can lead to new archaeological data that may supply important information about the palaeoenvironment and the age of deposits and which will help to improve the map reconstructions.

\section{Acknowledgements}

The presented research was funded by the EU Interreg 2 Seas programme (project 'Arch-Manche') and the Research 
Foundation Flanders (FW0) (project ‘Archaeological exploration across the land-sea boundary in the Doelpolder Noord area: impact of sea-level rise on the landscape and human occupation, from the prehistory to medieval times'). Iason Jongepier and Tim Soens acknowledge funding by the University of Antwerp Research Council ('Drowned but not deserted. Interactions between social and ecological resilience of estuarine landscapes after flooding. Test-case: the Waasland polders on the westbank of the river Scheldt (15th-18th centuries)'). Koen Deforce, Stijn Temmerman and Peter Vos are kindly acknowledged for their critical review of the paper. The authors would like to thank the two reviewers, Patrick Kiden and Cecile Baeteman, for their helpful comments.

\section{References}

Adams, R., Vermeire, S., De Moor, G., Jacobs, P., Louwye, S. \& Polfliet, T. 2002. Toelichting bij de Quartairgeologische kaart Kaartblad (15) Antwerpen Schaal 1:50 000. Vlaamse overheid, Departement Leefmilieu, Natuur en Energie, Dienst Natuurlijke Rijkdommen: 50 pp.

AGIV, 2000. Vectoriële versie van de Bodemkaart 1/20000. AGIV (Agentschap voor geografische informatie Vlaanderen), IWT, Laboratorium voor Bodemkunde van de Universiteit Gent (GIS-Vlaanderen).

Augustyn, B., 1977. Bijdrage tot het ontstaan en de vroegste geschiedenis van de Wase Polders - van de oudste tijden tot circa 1400. Annalen van de Koninklijke Oudheidkundige Kring van het Land van Waas 80: 5-97.

Augustyn, B., 1985. De turfwinnersdorpen Kieldrecht en Verrebroek in 1394: Twee stadia in de evolutie van een proto-industriële naar een agrarische produktiewijze. Annalen van de Koninklijke Oudheidkundige Kring van het Land van Waas 88: 241-256.

Augustyn, B., 1999. De veenontginning (12de-16de eeuw). Geschiedenis van volk en land van Beveren. Gemeente Beveren, Beveren, Belgium: 172 pp.

Baeteman, C., 1991. Chronology of the coastal plain development during the Holocene in West Belgium. Quaternaire 2(3/4): 116-125.

Baeteman, C., 1999. The Holocene depositional history of the palaeovalley of the IJzer (western Belgian coastal plain) with reference to the factors controlling the formation of intercalated peat beds. Geologica Belgica 2: 39-72.

Baeteman, C., 2007. Roman pea-extraction pits as possible evidence for the timing of coastal changes. An example from the Belgian coastal plain. In: Beenakker, J.J.M., Horsten, F.H. \& de Kraker, A.M.J. (eds): Landschap in ruimte en tijd. Aksant Academic Publishers (Amsterdam): 16-25.

Baeteman, C. \& Pieters, M., 2015. Hoe en waarom het landschap veranderde tijdens de Romeinse periode te Ra-versijde (Oostende, Belgische kustvlakte). In: Hameeuw, H. (ed.): Recent Archeologisch onderzoek in West-Vlaanderen. Vereniging voor Oudheidkundig Bodemonderzoek in West-Vlaanderen vzw (V.O.B.o.W.) (Roeselare): 1-25.

Baeteman, C. \& Verbruggen, C., 1979. A new approach to the evolution of the so-called surface peat in the Western Coastal Plain of Belgium. Aardkundige Dienst, Prof. Paper 1979/11 no. 167: 21 pp.

Bastiaens, J., Deforce, K., Klinck, B., Meersschaert, L., Verbruggen, C. \& Vrydaghs, L., 2005. Palaeobotanical analyses. In: Crombé, Ph. (ed.): The last hunter-gatherer-fishermen in Sandy Flanders (NW Belgium). The Verre- broek and Doel Excavation Projects (Vol. 1: Palaeo-environment, chronology and features). Archaeological Reports Ghent University 3, Academia Press (Ghent): 251-78.

Bats, M., 2007. The Flemish Wetlands: an archaeological survey of the valley of the river Scheldt. In: Barber, J., Clark, C., Cressey, M., Crone, A., Hale, A., Henderson, J., Housley, R., Sands, R. \& Sheridan, A. (eds): Archaeology from the Wetlands: Recent Perspectives. Proceedings of the 11th WARP Conference, Edinburgh 2005. Society of Antiquaries of Scotland (Edinburgh): 93-100 (WARP 0ccasional Paper 18).

Bell, M., 2007. Prehistoric coastal communities: the Mesolithic in Western Britain. Council for British Archaeology Research Report nr 149 (York): 250 pp.

Bengtsson, L. \& Enell, M., 1986. Chemical analysis. In: Berglund, B.E. (ed.): Handbook of Holocene palaeoecology and palaeohydrology. Wiley and Sons (New York): 423-451.

Birks, H.H. \& Birks, H.J.B., 2006. Multi-proxy studies in palaeolimnology. Vegetation History and Archaeobotany 15: 235-251.

Birks, H.H., Gelorini, V., Robinson, E. \& Hoek, W.Z., 2014. Impacts of palaeoclimate change 60000-8000 years ago on humans and their environments in Europe: integrating palaeoenvironmental and archaeological data. Quaternary International 378: 3-14.

Bogemans, F., 1997. Toelichting bij de Quartairgeologische kaart Kaartblad (1-7) Essen - Kapellen Schaal 1:50 000. Vlaamse overheid, Departement Leefmilieu, Natuur en Energie, Dienst Natuurlijke Rijkdommen: 38 pp.

Bogemans, F., Meylemans, E., Jacobs, J., Perdaen, Y., Storme, A., Verdurmen, I. \& Deforce, K., 2012. The evolution of the sedimentary environment in the lower River Scheldt valley (Belgium) during the last 13,000 a BP. Geologica Belgica 15(1-2): 105-112.

Borger, G.J., 1992. Draining-digging-dredging; the creation of a new landscape in the peat areas of the Low Countries. In: Verhoeven, J.T.A. (ed.): Fens and bogs in the Netherlands: vegetation, history, nutrient dynamics and conservation. Kluwer (Dordrecht, Boston, Londres): 131-171 (Geobotany, 18).

Bos, J., Huisman, D., Kiden, P., Hoek, W. \& van Geel, B., 2005. Early Holocene environmental change in the Kreekrak area (Zeeland, SW-Netherlands): a multi-proxy analysis. Palaeogeography, Palaeoclimatology, Palaeoecology 227: 259-289.

Boski, T., Moura, D., Veiga-Pires, C., Camacho, S., Duarte, D., Scott, D.B. \& Fernandes, S.G., 2002. Postglacial sea-level rise and sedimentary response in the Guadiana Estuary, Portugal/Spain border. Sedimentary Geology 150(1-2): 103-122.

Brand, K., 1983. Over het ontstaan en de ontwikkeling van de Hont of Westerschelde. Zeeuws tijdschrift 33(3): 99-110.

Crombé, Ph. (ed.), 2005. The last hunter-gatherer-fishermen in Sandy Flanders (NW Belgium). The Verrebroek and Doel excavation Projects. Volume 1: Palaeoenvironment, chronology and features. Archaeological Reports Ghent University 3, Academia Press (Ghent): 334 pp.

Crombé, Ph. \& Meganck, M., 1996. Results of an auger survey research at the Early Mesolithic site of Verrebroek "Dok" (East-Flanders, Belgium). Notae Praehistoricae 16: 101-115.

Crombé, Ph. \& Sergant, J., 2008. Tracing the Neolithic in the sandy lowland of Belgium: the evidence from Sandy Flanders. In: Fokkens, H., Coles, B., van Gijn, A., Kleijne, J., Ponjee, H. \& Slappendel, C. (eds): Between foraging and farming. An extended broad spectrum of papers presented to Leendert Louwe Kooijmans, Analecta Praehistorica Leidensia 40: 75-84. 
Crombé, Ph. \& Verhegge, J., 2015. In search of sealed Palaeolithic and Mesolithic sites using core sampling: the impact of grid size, meshes and auger diameter on the discovery probability. Journal of Archaeological Science 53: 445-458.

Crombé, Ph., Perdaen, Y. \& Sergant, J., 2005. Features. In: Crombé, Ph. (ed.): The last hunter-gatherer-fishermen in Sandy Flanders (NW Belgium). The Verrebroek and Doel excavation projects Vol. 1: Palaeo-environment, chronology and features. Archaeological Reports Ghent University 3, Academia Press (Ghent): 141-179.

Crombé, Ph., Sergant, J., Robinson, E. \& De Reu, J., 2011. Hunter-gatherer responses to environmental change during the Pleistocene-Holocene transition in the southern North Sea basin: Final Palaeolithic-Final Mesolithic land use in northwest Belgium. Journal of Anthropological Archaeology 30: 454-471.

Crombé, Ph., Van Strydonck, M., Boudin, M., Van den Brande, T., Derese, C., Vandenberghe, D., Van den Haute, P., Court-Picon, M., Verniers, J., Gelorini, V., Bos, J., Verbruggen, F., Antrop, M., Bats, M., Bourgeois, J., De Reu, J., De Maeyer, Ph., De Smedt, Ph., Finke, P., Van Meirvenne, M. \& Zwertvaegher, A., 2012. Absolute dating (14C and 0SL) of the formation of coversand ridges occupied by prehistoric hunter-gatherers in NW Belgium. Radiocarbon 54(3-4): 715-726.

Crombé, Ph., De Smedt, Ph., Davies, N.S., Gelorini, V., Zwertvaegher, A., Langohr, R., Van Damme, D., Demiddele, H., Van Strydonck, M., Antrop, M., Bourgeois, J., De Maeyer, Ph., De Reu, J., Finke, P., Van Meirvenne, M. \& Verniers, J., 2013. Hunter-gatherer responses to the changing environment of the Moervaart palaeolake (NW Belgium) during the Late Glacial and Early Holocene. Quaternary International 308-309: 162-177.

Crombé, Ph., Verhegge, J., Deforce, K., Meylemans, E. \& Robinson, E., 2015. Wetland landscape dynamics, Swifterbant land use systems, and the Mesolithic-Neolithic transition in the southern North Sea basin. Quaternary International 378: 119-133.

Cryns, J., Noens, G., Allemeersch, L., Bats, M., Cruz, F., Jongepier, I., Laloo, P., Rozek, J., Sergant, J., Soens, T., Verhegge, J. \& Windey, S., 2014. Verrebroek - Logistiek Park Waasland fase West. Een paleolandschappelijke en archeologische prospectie d.m.v. boringen en proefsleuven (03/2013 01/2014). GATE-rapport 73 (Bredene): 247 pp.

D'Alpaos, A., Lanzoni, S., Mudd, S., Fagherazzi, S., D'Alpaos, A., Lanzoni, S., Mudd, S. \& Fagherazzi, S., 2006. Modeling the influence of hydroperiod and vegetation on the cross-sectional formation of tidal channels. Estuarine, Coastal and Shelf Science 69(3-4): 311-324.

de Bont, C., 2014. Amsterdamse boeren. Een historische geografie van het gebied tussen de duinen en het gooi in de Middeleeuwen. Verloren (Hilversum): $352 \mathrm{pp}$.

De Brouwer, J., Crosato, A., Dankers, N., van Duin, W., Herman, P.M.J., van Raaphorst, W., Stive, M.J.F., Talmon, A.M., Verbeek, H., de Vries, M.B., van der Wegen, M. \& Winterwerp, J.C., 2001. Eco-morphodynamic processes in the Rhine-Meuse-Scheldt delta and the Dutch Wadden Sea. Delft Hydraulics report Z2817: $93 \mathrm{pp}$.

De Clercq, W., 2009. Extrema Gallarium. Zeeland en Noorwest-Vlaanderen in het Imperium Romanum. Zeeuws Tijdschrift 58(3-4): 6-34.

De Clercq, W. \& Van Dierendonck, R., 2009. Extrema Galliarum: NoordwestVlaanderen en Zeeland in het Imperium Romanum. Verbond voor oudheidkundig bodemonderzoek in 0ost-Vlaanderen (VOBOV-info): 34-75.
Deforce, K., 2011. Middle and late Holocene vegetation and landscape evolution of the Scheldt estuary. A palynological study of a peat deposit from Doel (N-Belgium). Geologica Belgica 14: 277-288.

Deforce, K., Gelorini, V., Verbruggen, C. \& Vrydaghs, L., 2005. Pollen and phytolith analyses. In: Crombé, Ph. (ed.): The last hunter-gatherer-fishermen in Sandy Flanders (NW-Belgium). The Verrebroek and Doel Excavation Projects. Vol. 1: Palaeo-environment, chronology and features. Archaeological Reports Ghent University 3, Academia Press (Ghent): 108-126.

Deforce, K., Bastiaens, J., Ervynck, A., Lentacker, A., Van Neer, W., Sergant, J. \& Crombé, Ph., 2013. Wood charcoal and seeds as indicators for animal husbandry in a wetland site during the late Mesolithic/early Neolithic transition period (Swifterbant culture, ca. 4600-4000 BC) in NW-Belgium. Vegetation History and Archaeobotany 22: 51-60.

Deforce, K., Bastiaens, J. \& Crombé, Ph., 2014a. A reconstruction of middle Holocene alluvial hardwood forests (Lower Scheldt River, N-Belgium) and their exploitation during the Mesolithic-Neolithic transition period (Swifterbant Culture, c. 4500-4000 BC). Quaternaire 25(1): 9-21.

Deforce, K., Storme, A., Bastiaens, J., Debruyne, S., Denys, L., Ervynck, A., Meylemans, E., Stieperaere, H., Van Neer, W. \& Crombé, Ph., 2014b. MiddleHolocene alluvial forests and associated fluvial environments: a multi-proxy reconstruction from the lower Scheldt, N Belgium. The Holocene 24(11): 15501564.

De Kraker, A.M.J., 2006. Flood events in the southwestern Netherlands and coastal Belgium, 1400-1953. Hydrological Sciences Journal-Journal des Sciences Hydrologiques 51(5): 913-929.

De Kraker, A. M. J., 2007. De ontwikkeling van het landschap. In: Wilssens, M. (ed.): Singelberg: hetkasteel en het land van Beveren. Lannoo (Tielt): 14-51.

De Langen, G. J., 1992. Middeleeuws Friesland: de economische ontwikkeling van het gewest 0ostergo in de vroege en volle Middeleeuwen. Noordhoff (Groningen): $395 \mathrm{pp}$.

Demey, D., Vanhoutte, S., Pieters, M., Deforce, K., Denys, L., Ervynck, A., Lentacker, A., Storme, A. \& Van Neer, W., 2013. Een dijk en een woonplatform uit de Romeinse periode in Stene (Oostende). Relicta 10: 7-70.

De Moor, G., 2002. Bijdrage tot de Quairtairgeologische kartering in Vlaanderen. Geologica Belgica 5 (1-2): 37-50.

De Moor, G. \& van de Velde, D., 1995. Toelichting bij de Quartairgeologische kaart Kaartblad (14) Lokeren Schaal 1:50 000. Vlaamse overheid, Departement Leefmilieu, Natuur en Energie, Dienst Natuurlijke Rijkdommen: 123 pp.

De Muynck, M., 1976. Het bedolven kultuurlandschap in de polders: een rekonstruktie uitgaande van luchtfoto's, toegepast op de 0ost-Vlaamse en enkele Zeeuws-Vlaamse Polders. PhD Thesis. Ghent University (Ghent): $266 \mathrm{pp}$.

Denys, L. 1993. Paleoecologisch diatomeëenonderzoek van de holocene afzettingen in de westelijke Belgische kustvlakte. PhD Thesis. University of Antwerp (Antwerp): $479 \mathrm{pp}$.

Denys, L. \& Baeteman, C., 1995. Holocene evolution of relative sea level and local mean high water spring tides in Belgium - a first assessment. Marine Geology 124: 1-19.

De Reu, J., Deweirdt, E., Crombé, Ph., Bats, M., Antrop, M., De Maeyer, P., De Smedt, Ph., Finke, P., Van Meirvenne, M., Verniers, J., Zwertvaegher, A. \& Bourgeois, J., 2011. Les tombelles de l'âge du bronze en Flandre sablonneuse (nord-ouest de la Belgique): un status quaestionis. Archäologisches Korrespondenzblatt 41(4): 491-505. 
Dijkema, K.S., Beeftink, W.G., Doody, J.P., Gehu, J.M., Heydemann, B. \& Rivas Martinez, M., 1984. Salt marshes in Europe. Council of Europe, Nature and environment series (Strasbourg) 30: $177 \mathrm{pp}$.

Dijkstra, J. \& Zuidhoff, F.S., 2011. Kansen op de kwelder. Archeologisch onderzoek op en rond negen vindplaatsen in het nieuwe tracé van de Rijksweg 57 en de nieuwe rondweg ter hoogte van Serooskerke (Walcheren). ADC Monografie (Amersfoort) 10: 35-58.

Gelorini, V., Meersschaert, L. \& Van Roeyen, J.-P., 2003. Archeobotanisch onderzoek van enkele laat- en postmiddeleeuwse archeologische contexten uit de onderzoekszone Verrebroekdok (Beveren, Prov. Oost-Vlaanderen). Archeologie in Vlaanderen VII 1999-2000: 200-224.

Gelorini, V., Verleyen, E., Verbruggen, C. \& Meersschaert, L., 2006. Paleoecologisch onderzoek van een Holocene sequentie uit het Deurganckdok te Doel (Wase Scheldepolders, Noord-België). BELGE0 3: 243-264.

Gottschalk, M.K.E., 1984. De Vier Ambachten en het Land van Saaftinge in de middeleeuwen: een historischgeografisch onderzoek betreffende 0ost ZeeuwsVlaanderen c.a.. Van Gorcum (Assen, the Netherlands): 589 pp.

Guns, P., 1975. Historische evolutie van het polderlandschap langs de linker Scheldeoever. Waterbouwkundig Laboratorium 1933-2008. Vlaamse Overheid, Departement Mobiliteit en Openbare werken: 78 pp.

Heyse, I. \& De Moor, G., 1979. Morphology of Würm Lateglacial and Holocene deposits in the Flemish valley (North Belgium). Acta Universitatis Ouluensis A Scientiae Rerum Naturalium 82: 121-131.

Hijma, M.P. \& Cohen, K.M., 2011. Holocene transgression of the Rhine river mouth area, The Netherlands/Southern North Sea: palaeogeography and sequence stratigraphy. Netherlands Journal of Geosciences 58: 1453-1485.

Jacobs, P., De Ceukelaire, M., De Breuck, W. \& De Moor, G., 1993. Geologische kaart van België, Vlaams gewest, Kaartblad (14) Lokeren Schaal 1:50 000. Vlaamse overheid, Departement Leefmilieu, Natuur en Energie, Dienst Natuurlijke Rijkdommen.

Jacobs, P., Polfliet, T., De Ceukelaire, M. \& Moerkerke, G., 2010. Geologische kaart van België, Vlaams gewest, Kaartblad (1-7) Essen - Kapellen Schaal 1:50 000. Vlaamse overheid, Departement Leefmilieu, Natuur en Energie, Dienst Natuurlijke Rijkdommen.

Janssens, W. \& Ferguson, D.K., 1985. The palaeoecology of the Holocene sediments at Kallo, Northern Belgium. Review of Palaeobotany and Palynology 46: 81-95.

Jongepier, I., Soens, T., Thoen, E., Eetvelde, V., Crombé, Ph. \& Bats, M., 2011. The brown gold: a reappraisal of medieval peat marshes in Northern Flanders (Belgium). Water History 3: 73-93.

Jongepier, I., Soens, T. \& Temmerman, S., 2012. Poldercartografie. De rol van kaarten bij bedijkingen en landschapstransformatie. In: 0oghe, B., Goossens, C. \& Segers, Y. (eds): Van brouck tot dyckagie. Vijf eeuwen Wase polders. Abimo (Sint-Niklaas): 45-68.

Jongepier, I., Soens, T., Temmerman, S., Missiaen, T. \& De Wit, B., $2015 \mathrm{a}$. Assessing the planimetric accuracy of historical maps (sixteenth to nineteenth centuries). New methods and potential for coastal landscape reconstruction. Cartographic Journal, in press (DOI: 10.1179/1743277414Y. 0000000095).

Jongepier, I., Wang, C., Missiaen, T., Soens, T. \& Temmerman, S., 2015b. Intertidal landscape response to dike breaching and (gradual) re-embankment: a combined and historical and geomorphological reconstruction. Geomorphology 236: 64-78.
Kasse, C. K., 2002. Sandy aeolian deposits and environments and their relation to climate during the Last Glacial Maximum and Lateglacial in northwest and central Europe. Progress in Physical Geography 26(4): 507-532.

Kiden, $\boldsymbol{P} .$, 1989. Holocene water level movements in the lower Scheldt perimarine area. In: Baeteman, C. (ed.): Quaternary sea-level investigations from Belgium: a contribution to IGCP Project 200. Professional Paper, Geological Survey of Belgium (Brussels): 1-19.

Kiden, $\boldsymbol{P}_{.}, 1991$. The Lateglacial and Holocene Evolution of the Middle and Lower Scheldt, Belgium. In: Starkel, K.J. and Thornes, J.B. (eds): Temperate palaeohydrology. John Wiley \& Sons (Chichester): 283-299.

Kiden, $\boldsymbol{P} ., 1995$. Holocene relative sea-level change and crustal movement in the southwestern Netherlands. Marine Geology 124: 21-41.

Kiden, P., 2006. De evolutie van de Beneden-Schelde in België en ZuidwestNederland na de laatste ijstijd. BELGE0 3: 279-294.

Kiden, P. \& Verbruggen, C., 2001. Het verhaal van een rivier: de evolutie van de Schelde na de laatste ijstijd. In: Bourgeois, J., Crombé, P., De Mulder, G. \& Rogge, M. (eds): Een in duik in het verleden. Schelde, Maas en Rijn in de pre- en protohistorie. Publicaties van het Provinciaal Museum van Zuid-0ostVlaanderen - site Velzeke 4: 11-35.

Knol, E., 2013. Moorkolonisation und Deichbau als Ursache von Flutkatastrophen: das Beispiel der nördlichen Niederlande. Siedlungs- und Küstenforschung im Südlichen Nordseegebiet 36: 157-170.

Leenders, K., 1986. 2000 jaar kustontwikkeling van Cap Griz Nez tot Hoek van Holland. Report nr. NZ-N-86.19. Rijkswaterstaat, taakgroep 1000 van het project kustgenese (Rijswijk): 44pp.

Leenders, K., 1989. Verdwenen venen: een onderzoek naar de ligging en exploitatie van thans verdwenen venen in het gebied tussen Antwerpen, Turnhout, Geertruidenberg en Willemstad (1250-1570). Reeks Landschapsstudies, Gemeentekrediet (Brussel): $351 \mathrm{pp}$.

Ligtendag, W.A., 1995. De Wolden en het water: de landschaps- en waterstaatsontwikkeling in het lage land ten oosten van de stad Groningen vanaf de volle middeleeuwen tot c. 1870. Regio- en landschapsstudies van de Stichting historisch onderzoek en beleid II (Groningen): $368 \mathrm{pp}$.

Lunne, T., Robertson, P.K. \& Powell, J.J.M., 1997. Cone penetration testing in geotechnical practice. Spon Press Taylor \& Francis Group (London): 305 pp.

Mauri, A., Davis, B.A.S., Collins, P.M. \& Kaplan, J.O., 2015. The climate of Europe during the Holocene: a gridded pollen-based reconstruction and its multi-proxy evaluation. Quaternary Science Reviews 112: 109-127.

Mayle, F. \& Iriarte, J., 2014. Integrated palaeoecology and archaeology: a powerful approach for understanding Pre-Columbian Amazonia. Journal of Archaeological Sciences 51: 54-64.

Meersschaert, L., Van Roeyen, J.-P. \& Verbruggen, C., 2006. Geomorfologisch, geoarcheologisch, paleoecologisch en paleobotanisch onderzoek van de havenuitbreidingswerken op de linker Scheldeoever ten noorden van Antwerpen. BELGE0 3: 183-203.

Meire, P. \& Kuijken, E., 1988. Het land van Saeftinge, slikken en schorren: ecologische betekenis van getijdengebieden langs de Schelde. Water 43: 214222.

Mercuri, A.M., Allevato, E., Arobba, D., Bandini Mazzanti, M., Bosi, G., Caramiello, R., Castiglioni, E., Carra, M.E., Celant, A., Costantini, L., Di Pasquale, G., Fiorentino, G., Florenzano, A., Guido, M., Marchesini, M., Mariotti Lippi, M., Marvelli, S., Miola, A., Montanari, C., Nisbet, R., PeñaChocarro, L., Perego, R., Ravazzi, C., Rottoli, M., Sadori, L., Ucchesu, M. 
\& Rinaldi, $\boldsymbol{R}_{\text {., 2014. Pollen and macroremains from Holocene archaeological }}$ sites: a dataset for the understanding of the bio-cultural diversity of the Italian landscape. Review of Palaeobotany and Palynology 218: 250-266.

Meylemans, E., Bogemans, F., Storme, A., Perdaen, Y., Verdurmen, I. \& Deforce, K., 2013. Lateglacial and Holocene fluvial dynamics in the Lower Scheldt basin (N-Belgium) and their impact on the presence, detection and preservation potential of the archaeological record. Quaternary International 308-309: 148-161.

Mijs, M., 1973. De landschapsgeschiedenis van de Scheldepolders ten noorden van Antwerpen. Bijdrage tot de historische geografie van de Scheldepolders. Tijdschrift van de Belgische Vereniging voor Aardrijkskundige Studies (D/1973/0468/2): 40-124.

Minnaert, G. \& Verbruggen, C., 1986. Palynologisch onderzoek van een veenprofiel uit het Doeldok te Doel. Bijdragen van de Archeologische Dienst Waasland 1: 201-208.

Missiaen, T., Slob, E. \& Donselaar, M.E., 2008. Comparing different shallow geophysical methods in a tidal estuary, Verdronken Land van Saeftinge, Western Scheldt, The Netherlands. Netherlands Journal of Geosciences 87(2): 151-164.

Missiaen, T., Verhegge, J., Heirman, K. \& Crombé, Ph., 2015. Potential of Cone Penetrating Testing for mapping deeply buried palaeolandscapes in the context of archaeological surveys in polder areas. Journal of Archaeological Science 55: 174-187.

Moore, P.D., Webb, J.A. \& Collinson, M.E., 1991. Pollen analysis (2nd edition). Cambridge University Press (Cambridge): 216 pp.

Munaut, A.-V., 1967. Recherches paléo-écologiques en Basse et Moyenne Belgique. Acta Geographica Lovaniensia 6: $191 \mathrm{pp}$.

Nelle, O., Dreibrodt, S. \& Dannath, Y., 2010. Combining pollen and charcoal: evaluating Holocene vegetation composition and dynamics. Journal of Archaeological Science 37: 2126-2135.

Ovaa, I., Van der Meer, K. \& Steur, G.G.L., 1957. De bodemgesteldheid van Westelijk Zeeuws-Vlaanderen. Stichting voor Bodemkartering (Wageningen), rapport nr. 455.

Perdaen, Y., Sergant, J. \& Crombé, Ph., 2004. Early Mesolithic landscape-use and site-use in northwestern Belgium: the evidence from Verrebroek "Dok". In: Crombé, Ph. (ed.): Proceedings of the symposium "Landscape-Use during the Final Palaeolithic and Mesolithic in NW-Europe; The Formation of Extensive Sites and Site-Complexes". British Archaeological Reports, International Series 1302: 11-18.

Reimer, P.J., Bard, E., Bayliss, A., Beck, J.W., Blackwell, P.G., Ramsey, C.B., Buck, C.E., Cheng, H., Edwards, R.L., Friedrich, M., Grootes, P., Guilderson, T., Haflidason, H., Hajdas, H., Hatté, C., Heaton, T., Hoffmann, D., Hogg, A., Hughen, K., Kaiser, K., Kromer, B., Manning, S., Niu, M., Reimer, R., Richards, D., Scott, E., Southon, J., Staff, R., Turney, C. \& van der Plicht, J., 2013. IntCal13 and Marine13 radiocarbon age calibration curves 0-50,000 years cal BP. Radiocarbon 55(4): 1869-1887.

Rippon, S., 2000. The transformation of coastal wetlands: exploitation and management of marshland landscapes in north west Europe during the Roman and medieval periods. 0xford University Press (0xford): 332 pp.

Rippon, S., 2002. Romney Marsh: evolution of the historic landscape and its wider significance. In: Long, A., Hipkin, S. \& Clarke, H. (eds): Romney Marsh: coastal and landscape change through the ages. Oxford University School of Archaeology Monograph (0xford) 56: 84-100.
Sergant, J., Crombé, Ph. \& Perdaen, Y., 2006. The 'invisible' hearths: a contribution to the discernment of Mesolithic non-structured surface hearths. Journal of Archaeological Science 33: 999-1007.

Sergant, J., Bats, M., Noens, G., Lombaert, L. \& D'Hollander, D., 2007. Voorlopige resultaten van noodopgravingen in het afgedekte dekzandlandschap van Verrebroek - Aven Ackers (Mesolithicum, Neolithicum). Notae Praehistoricae 27: 101-107.

Sier, M.M. (ed.), 2003. Ellewoutsdijk in de Romeinse tijd. ADC rapport 200 (Amersfoort): $198 \mathrm{pp}$.

Snacken, $\boldsymbol{F}_{\text {., }}$ 1964. De ontwikkeling van het Scheldepolderlandschap. Verslagboek $4^{\mathrm{e}}$ Int. Havencongres Antwerpen 22-27 juni 1964: 485-490.

Soens, T., 2013. The origins of the Western Scheldt. Environmental transformation, storm surges and human agency in the Flemish coastal plain (12501600). In: Thoen, E., Borger, G. J., De Kraker, A., Soens, T., Tys, D., Vervaet, L. \& Weerts, H. (eds): Landscapes or seascapes? The history of the coastal environment in the North Sea area reconsidered. Comparative Rural History of the North Sea Area 13: 287-312.

Soens, T. \& Thoen, E., 2009. Mais où sont les tourbières d'antan? Géographie, chronologie et stratégies économiques du tourbage en Flandre Maritime (12e16e siècles). Aestuaria, Histoire et Terres Humides 14: 45-60.

Soens, T., Tys, D. \& Thoen, E., 2014. Landscape transformation and social change in the North Sea Polders, the example of Flanders (1000-1800 AD). Siedlungsforschung: Archäologie, Geschichte, Geographie 31: 133-160.

Thoen, $\boldsymbol{H}$. (ed.), 1989. Temse en de Schelde van ijstijd tot de Romeinen. Gemeentekrediet (Brussel): $128 \mathrm{pp}$.

Van Dam, P., 2001. Sinking peat bogs: environmental change in Holland, 13501550. Environmental History 6: 32-46.

Vandenbruwaene, W., Meire, P. \& Temmerman, S., 2012. Formation and evolution of a tidal channel network within a constructed tidal marsh. Geomorphology 151/152: 114-125.

Van der Spek, A., 1994. Large-scale evolution of Holocene tidal basins in the Netherlands. PhD Thesis. Utrecht University (Utrecht): 191 pp.

Van der Spek, A. \& Beets, D., 1992. Mid-Holocene evolution of a tidal basin in the western Netherlands: a model for future changes under conditions of accelerated sea-level rise? Sedimentary Geology 80: 185-197.

Van Gerven, $R_{.}, 1977$. De Scheldepolders van de Linkeroever (Land van Waas en Land van Beveren): bijdrage tot de geschiedenis van natuur-land-volk. Sint Niklaas: $780 \mathrm{pp}$.

Van Neer, W., Ervynck, A., Lentacker, A., Bastiaens, J., Deforce, K., Sergant, J. \& Crombé, Ph., 2013. Hunting, gathering, fishing and herding: animal exploitation in Sandy Flanders (NW Belgium) during the second half of the 5th millennium BC. Journal of Environmental Archaeology 18(2): 87-101.

Van Roeyen, J.-P. (ed.), 2007. Paleolandschappelijk en archeologisch onderzoek van de te realiseren natuurcompensatiezone "Weidevogelgebied Doelpolder Noord en Kreek" in het kader van de bouw van het Containergetijdendok-West (Gemeente Beveren). Eindrapport: paleolandschappelijke en archeologische screening aan de hand van boringen en inventarisatie (parentheses 1 en 2). Archeologische Dienst Waasland (Sint-Niklaas): 102 pp.

Van Rummelen, F., 1965. Toelichtingen bij de Geologische Kaart van Nederland, 1:50.000; Bladen Zeeuwsch-Vlaanderen Wesxt en Oost. Rijks Geologische Dienst (Haarlem): 79 pp.

Van Strydonck, M., 2005. Radiocarbon dating. In: Crombé, Ph. (ed.): The last hunter-gatherer-fishermen in sandy Flanders (NW Belgium). The Verrebroek 
and Doel excavation projects (Vol. 1: Palaeo-environment, chronology and features). Archaeological Reports Ghent University 3, Academia Press (Ghent): 180-212.

Verbruggen, C. \& Denys, L., 1995. Early tidal influence on the Lower Schelde, Belgium. Aardkundige Mededelingen 6: 167-169.

Verbruggen, C., Denys, L. \& Kiden, P., 1991. Paleo-ecologische en geomorfologische evolutie van Laag- en Midden-België tijdens het Laat-Kwartair. De Aardrijkskunde 3: 357-376.

Verbruggen, C., Denys, L. \& Kiden, P., 1996. Palaeoecological events in Belgium during the last 13,000 years with special reference to sandy Flanders. In: Berglund, B.E., Ralska-Jasiewiczowa, M. \& Wright, H.E. (eds.): Palaeoecological events during the last 15000 years: regional syntheses of palaeoecological studies of lakes and mires in Europe. John Wiley \& Sons (Chichester): 553-574.

Verhegge, J., 2015. Spatial and chronological prehistoric landscape reconstruction using geoarchaeological methods in the lower Scheldt floodplain (NW Belgium). PhD Thesis. Ghent University (Ghent): 247 pp.

Verhegge, J., Missiaen, T., Van Strydonck, M. \& Crombé, Ph., 2014. Chronology of wetland hydrological dynamics and the Mesolithic-Neolithic transition along the Lower Scheldt: a Bayesian approach. Radiocarbon 56: 883-898.

Verhoeve, A. \& Verbruggen, C., 2006. Het Meetjesland. Bodem en landschap in historisch perspectief. BELGE0 7: 205-218.

Vos, P.C., 2015. Origin of the Dutch coastal landscape. Long-term evolution of the Netherlands during the Holoce, described and visualised in national, regional and local palaeographical maps series. Barkhuis (Groningen): $359 \mathrm{pp}$.

Vos, P.C. \& de Wolf, H., 1993. Diatoms as a tool for reconstructing sedimentary environments in coastal wetlands; methodological aspects. Hydrobiologia 269: 285-296.
Vos, P.C. \& Knol, E., 2015. Holocene landscape reconstruction of the Wadden Sea area between Marsdiep and Weser. In: Vos, P., Origin of the Dutch coastal landscape. Long-term evolution of the Netherlands during the Holocene, described and visualised in national, regional and local palaeographical maps series. Barkhuis (Groningen): 202-229.

Vos, P.C. \& van Heeringen, R.M., 1997. Holocene geology and occupation history of the province of Zeeland. In: Fischer, M.M. (ed.): Holocene evolution of Zeeland (SW Netherlands). Mededelingen Nederlands Instituut voor Toegepaste Geowetenschappen 59: 5-109.

Vos, P.C., Moree, J. \& Zeiler, F.D., 2002. Delta-2003, 5000 jaar terugblik, kaartatlas met toelichting. Landschapsreconstructie van de kustdelta van ZW Nederland in opdracht van het project GEOMOD van het RIKZ van het Ministerie van Verkeer en Waterstaat. TNO rapport NITG 02-096-B.

Vos, P.C., de Koning, R. \& van Eerden, R., 2015. Landscape history of the 0er-IJ tijdal system, Noord-Holland (The Netherlands). In: Vos, P. (ed.), Origin of the Dutch coastal landscape. Long-term evolution of the Netherlands during the Holocene, described and visualised in national, regional and local palaeographical maps series. Barkhuis (Groningen): 98-201.

Wang, C. \& Temmerman, S., 2013. Does bio-geomorphic feedback lead to abrupt shifts between alternative landscape states? An empirical study on intertidal flats and marshes. Journal of Geophysical Research - Earth Surface 118: 229240.

Wilssens, M., Bartholomieux, B., De Kraker, A., De Meulemeester, J., Poschet, K., Van Daele, R., Verelst, D. \& Willems, R., 2007. Singelberg, Het kasteel en het land van Beveren. Lannoo (Tielt): $270 \mathrm{pp}$.

Woodruff, J. D., Irish, J. L. \& Camargo, S. J., 2013. Coastal flooding by tropical cyclones and sea-level rise. Nature 504: 44-52. 